\title{
チューイン法による関節窩形態の変化に関する研究
}

一セントラルベアリングプレートの形態による影響一

林清 佐

\author{
A Study on Morphological Changes of the \\ Glenoid Fossa by the Chew-in Method \\ - With Reference to Effect of the Form of Central Bearing Plate-
}

\section{LIN Chin-Cho}

\section{第 1 章 緒 言}

下頡運動に関する研究は 1889 年 Luce ${ }^{1)}$ が下颚運動を 測定して以来, 約 1 世紀の間に下顎の限界運動および機 能運動の研究・解析など数多く報告されてきた ${ }^{2 \sim 54)}$. 下 影運動を解析することは, 口腔内に装着する修復物が歯 および歯周組織と調和するだけでなく，顎口腔系を構成 する筋・神経機構との調和をはかり，さらに䫟関節症の 診断, 治療, 咬合再構成（オーラルリハビリテーショ ン)などに非常に重要である. したがって患者の下䫟運 動を正確に再現すべく，種々の調節性をそなえた精密な 咬合器が開発されている.下顎運動の基礎的研究は解剖 学的検討 ${ }^{7-10)}$, チェックバイト法 ${ }^{11 ~ 15), ~ ハ ゚ ン ト ク ゙ ラ フ ~}$

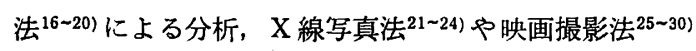
などにより解明されつつあるが，実際に咬合器を使用す るための下顎運動軌跡記録法は少ない. その際セントラ ルベアリングプレート（以下 C.B.P. と略す）とセント ラルベアリングスクリュウ(以下 C.B.S. と略す)によ りある程度の咬合垂直間距離 (以下 V.D. と略す) を増 加させて採得している. なお C.B.P. の形態が異なるこ とによる、いわゆるアンテリオールガイダンスを変化さ せた時, 咬合器顆頭球の動きを支配するポステリオール ガイダンスー影響があるであろうと考えられているが,

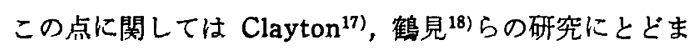

日本大学大学院歯学研究科歯科補緅学専攻（指導 : 中沢 靖 教授)

Department of Prosthodontics, Nihon University Graduate School of Dentistry (Director : Prof. Yasushi Nakazawa)

昭和 53 年 12 月 12 日受付
る.

そこで，今回著者はチューイン法を用い，咬合器の顆 頭球の運動軌跡として調製する $\mathrm{TMJ}$ 咬合器のレジンフ オッサの形態を三次元的に計測 L, C.B.P. の形態を平 面, 凸面および凹面の 3 種に変えた時の1)レジンフォッ サつまり下顊頭の運動経路に相当すると考えられるもの の形態の変化, 2) TMJ 咬合器の再現性, 3)機能運動の 立場から最も大切と考えられる中心位から $2 \mathrm{~mm}$ の範囲 への影響などについて, 分析, 検討した.

\section{第 2 章 材料と方法}

\section{被験者および材料}

（1）被験者は日本大学歯学部学生 3 名で (20 歳代男性

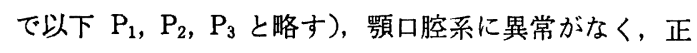
常な歯列と歯周組織を有しかつ歯の欠損と欠如がないも のである.

（2）平面の C.B.P. は Dentsply 社製口腔内ゴシック アーチトレーサ, 厚み $1 \mathrm{~mm}$ のステンレス板を用いて, 1 辺が $18 \mathrm{~mm}$ の正方形に切断したものを使用した. ま た凸面と凹面の C.B.P. は、スチュアート咬合器の半径 2インチのプラスチック製サイドエミネンシアガイドプ レートを利用して, 超硬石童で陰形模型を採得し,つい で凸面および凹面のワックス模型を製作し，磨耗防止の ために上䫑レジンクラッチの C.B.S. の先端とともに松 風社製スマロイコバルトクロームで鋳造した.

(3) これらの平面, 凸面および凹面の 3 種の C.B.P. を可換性かつ正しい位置に位置づけるために 1 辺が $20 \mathrm{~mm}$, 高さ $2.5 \mathrm{~mm}$ の真鍮製ボックスを調製し, 下䫛 レジンクラッチの真中に埋め込み, このボックス内に 

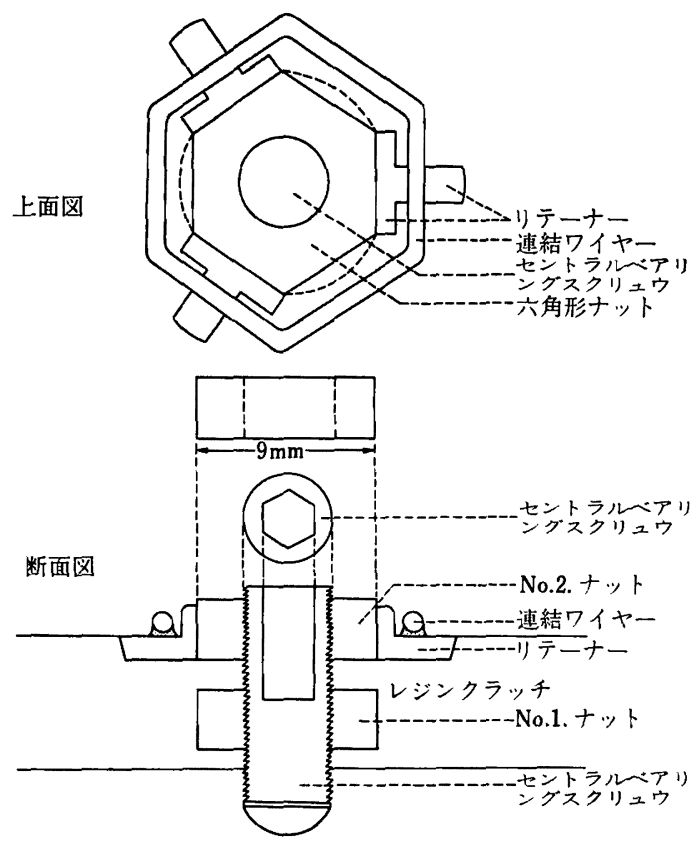

図 1 セントラルベアリングスクリュウ自家製固定装置

C.B.P. を 4 個のネジ（值径 $1.7 \mathrm{~mm}$, 長さ $3 \mathrm{~mm}$, ナッ トつき) とレジンで固定した.

(4) 咬合器は TMJ 咬合器と改良したその付属品を使 用した.レジンクラッチの形成, チューインおよびレジ ンフォッサの形成などすべての臨床操作は TMJ 咬合器

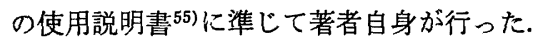

（5）上頡レジンクラッチに取り付けた C.B.S. は，チ ユーインを数回繰り返すと回転上昇し V.D. が変化する ので，これを防止するため図 1 に示すような固定装置を 作製した.

\section{研究方法}

(1) レジンクラッチおよびレジンフォッサの形成

C.B.S. と 3 種の形態の異なる C.B.P. をそれぞれ上下 レジンクラッチに取り付けて被験者の口腔内に装着し， オトガイ部を軽く押しながら中心位へ誘導し, 側方運動 は被験者自身にて側方運動を行わせ, 特に下顎角部を側 方へ押さずチューインさせた. これを 3 種類の C.B.P. につき 3 回ずつ計 9 回行った. なお各被験者について中 心位における V.D. を一定に規制するために，上下クラ ッチの前方 3 カ所に松風社製スフェリガルアマルガムを 冭填し, 研磨後その表面に木綿針を用い標識点を設定し た.チューイン終了後コアー採得時にキャリパーを用い

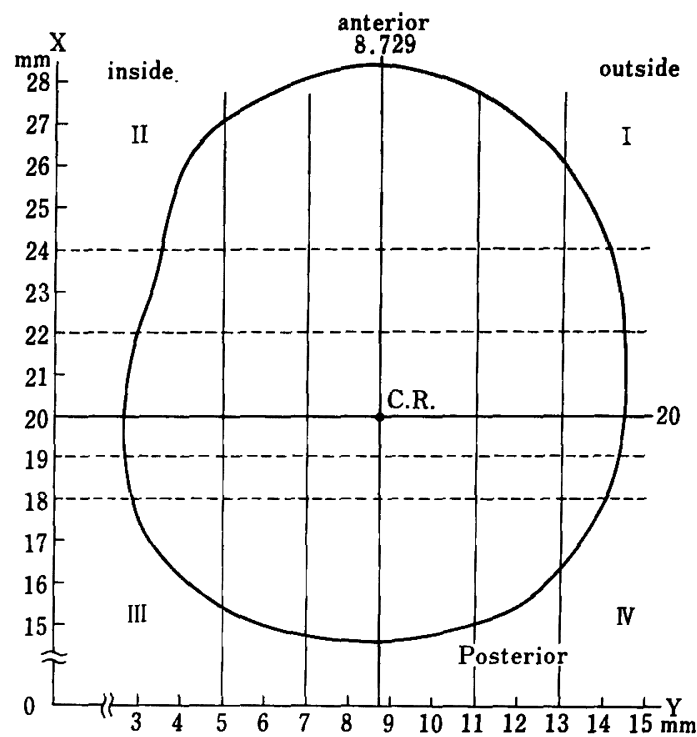
注)—： sagittal plane(矢状面)
frontal plane(前頭面)
I : 第 I 象現
II : 第 II 象現
III：第III象現 IV : 第 IV 象現

図 2 左側レジンフォッサ内の計測部代表例とその象現

て V.D. が一定であることを確認した.

クラッチ装着時の中心位における V.D. が咬頭嵌合位 からどのくらい増加しているかを $\frac{43}{43} \mid$ 間の固有歯肉に入 墨した標識点間距離で計測したところ， $\mathrm{P}_{2}$ は $11.5 \mathrm{~mm}$, $\mathrm{P}_{2}$ は $11.2 \mathrm{~mm}, \mathrm{P}_{3}$ は $10.8 \mathrm{~mm}$ であった.

クラッチの咬合器付着はヒンジアキシスを用いフェス ボートランスファーし, Whip-Mix 社製マウンティング ストーン（硬化膨張率 $0.09 \%$ ) を用い 2 度に分け付着し た. レジンフォッサの形成時には TMJ 咬合器の顆頭間 距離は最内方の $82 \mathrm{~mm}^{56,57)}$ に固定し左右側のレジンフ オッサを同時に形成した. 形成にあたっては第 1 報 ${ }^{56)}$ 結果より，リライン法を用いた.

(2) 計測方法

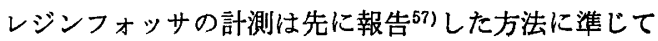
行った. なお, 本研究における計測は左側のみについて 行った.

\section{第 3 章 成 精}

3 種の形態の異なる C.B.P. を用いて形成したレジン フォッサの 3 次元的形態を総計測点 6,000 点について計 
表 1 被験者 $\mathrm{P}_{1}$ について平面, 凸面, 凹面のプレートにおけすレジン フォッサのY 軸上での Z 座標の平均值と統計值

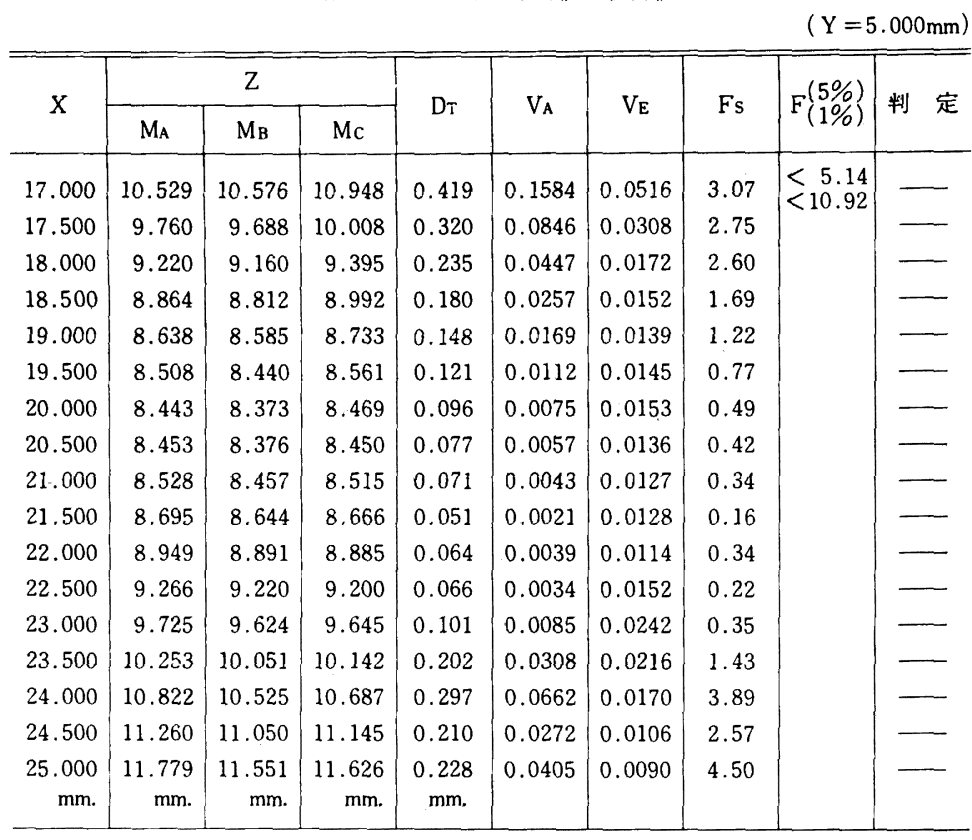

(注) 表1〜15における略号は以下に記す.

$$
\begin{aligned}
& X: X \text { 軸座標値 } \\
& Y: Y \text { 軸座標値 } \\
& \mathrm{DT}=3 \text { つのプレート間のばらつき } \\
& \mathrm{Z}: \mathrm{Z} \text { 軸座標值 } \\
& \mathrm{MA}: \text { 平面プレートの平均值 } \\
& \mathrm{MB} \text { : 凸面プレートの平均値 } \\
& \mathrm{MC} \text { : 凹面プレートの平均値 } \\
& \text { なお有意差の判定は } \mathrm{F}(5 \%)=5.14, \mathrm{~F}(1 \%)=10.92 に て \text { 行った。 } \\
& \mathrm{VA}=\text { 級間不偏分散值 (プレート間) } \\
& \mathrm{VE}=\text { 級内不偏分散値 }(\text { チューイン間) } \\
& \text { 自由度は級内 (6) 級間 (2) }
\end{aligned}
$$

測し，分析，検討した。 その結果いずれも有意差が認め られなかったので，今回はその代表として，図 2 に示す ように矢状面上では中心位の $\mathrm{Y}=8.729 \mathrm{~mm}$ ，中心位よ り内側の $\mathrm{Y}=7.000 \mathrm{~mm}$ 抢よび $\mathrm{Y}=5.000 \mathrm{~mm}$ と中心位 より外側の $\mathrm{Y}=11.000 \mathrm{~mm}$ および $\mathrm{Y}=13.000 \mathrm{~mm}$, 前頭 面上では中心位の $X=20.000 \mathrm{~mm}$, 中心位より前方の $\mathrm{X}=22.000 \mathrm{~mm}$ および $24.000 \mathrm{~mm}$, 後方の $\mathrm{X}=19.000$ $\mathrm{mm}$ および $\mathrm{X}=18.000 \mathrm{~mm}$ におけるそれぞれの C.B.P. ごとの Z座標における平均值と統計值を表 1 15に示 す.なお，本論文における再現性とは， C.B.P.ごとの 平均値のばらつき41 43,57)をもって検討した．これらを わかりやすくするために, 矢状面, 前頭面切惊して たのが図 3〜32 である。
A) 矢状面
(1) $Y=8.729 \mathrm{~mm}$ (中心位) 線上

矢状面で中心位を通る $\mathrm{Y}=8.729 \mathrm{~mm}$ の線上で $200 \mu$ 以下のばらつきを示したのは, $\mathrm{P}_{1}$ および $\mathrm{P}_{3}$ では前方約 $6.0 \mathrm{~mm}$ まで（図 3,5 ) と $\mathrm{P}_{2}$ で前方約 $4.5 \mathrm{~mm}$ まで（図 4) とであった.

(2) $\mathrm{Y}=7.000 \mathrm{~mm}$ (中心位より内側) 線上

矢状面上で中心位を通る位置 $(\mathrm{Y}=8.729 \mathrm{~mm})$ より内 側の $\mathrm{Y}=7.000 \mathrm{~mm}$ 線上で $200 \mu$ のばらつきを示したの は， $\mathrm{P}_{1}$ で前方約 $4.0 \mathrm{~mm}$ まで (図 6), $\mathrm{P}_{2}$ で前方約 3.5 $\mathrm{mm}$ まで（図 7)， $\mathrm{P}_{3}$ で前方約 $6.0 \mathrm{~mm}$ まで（図 8) とで あった.

(3) $\mathrm{Y}=5.000 \mathrm{~mm}$ (中心位上り内側) 線上

矢状面上で中心位を通る位置 $(\mathrm{Y}=8.729 \mathrm{~mm})$ より内 側の $\mathrm{Y}=5.000 \mathrm{~mm}$ の線上で $200 \mu$ 以下のばらつきを示 したのは， $P_{1}$ および $P_{2}$ では前方約 $3.0 \mathrm{~mm}$ まで（図 9 , 10）と $\mathrm{P}_{3}$ で前方約 $2.5 \mathrm{~mm}$ まで（図 11）とであった.

(4) $\mathrm{Y}=11.000 \mathrm{~mm}$ (中心位上り外側) 線上 
表 2 被験者 $\mathrm{P}_{1}$ について平面, 凸面, 凹面のプレートにおけるレジン フォッサのY 軸上での $Z$ 座標の平均值と統計值

\begin{tabular}{|c|c|c|c|c|c|c|c|c|c|}
\hline \multirow{2}{*}{$X$} & \multicolumn{3}{|c|}{$Z$} & \multirow{2}{*}{ DT } & \multirow{2}{*}{$\mathrm{V}_{\mathrm{A}}$} & \multirow{2}{*}{$V_{E}$} & \multirow{2}{*}{ Fs } & \multirow{2}{*}{$F_{(1 \%)}^{(5 \%)}$} & \multirow{2}{*}{ 判定 } \\
\hline & $\mathrm{M}_{\mathrm{A}}$ & $\mathrm{MB}_{\mathrm{B}}$ & $\mathrm{Mc}$ & & & & & & \\
\hline 16.500 & 9.665 & 9.719 & 9.966 & 0.301 & 0.0773 & 0.0179 & 4.32 & $\begin{array}{l}<5.14 \\
<10.92\end{array}$ & \\
\hline 17.000 & 8.915 & 8.980 & 9.144 & 0.229 & 0.0417 & 0.0124 & 3.36 & & - \\
\hline 17.500 & 8.404 & 8.457 & 8.584 & 0.180 & 0.0257 & 0.0081 & 3.17 & & \\
\hline 18.000 & 8.051 & 8.076 & 8.177 & 0.126 & 0.0133 & 0.0056 & 2.37 & & \\
\hline 18.500 & 7.789 & 7.804 & 7.888 & 0.099 & 0.0085 & 0.0044 & 1.93 & & \\
\hline 19.000 & 7.608 & 7.608 & 7.678 & 0.070 & 0.0046 & 0.0036 & 1.28 & & \\
\hline 19.500 & 7.511 & 7.503 & 7.551 & 0.048 & 0.0020 & 0.0023 & 0.87 & & \\
\hline 20.000 & 7.442 & 7.445 & 7.484 & 0.042 & 0.0017 & 0.0014 & 1.21 & & 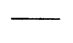 \\
\hline 20.500 & 7.441 & 7.431 & 7.463 & 0.032 & 0.0008 & 0.0016 & 0.50 & & \\
\hline 21.000 & 7.513 & 7.482 & 7.512 & 0.031 & 0.0010 & 0.0020 & 0.50 & & \\
\hline 21.500 & 7.617 & 7.591 & 7.605 & 0.026 & 0.0005 & 0.0019 & 0.26 & & - \\
\hline 22.000 & 7.773 & 7.791 & 7.769 & 0.022 & 0.0004 & 0.0022 & 0.18 & & - \\
\hline 22.500 & 7.986 & 8.023 & 7.998 & 0.037 & 0.0011 & 0.0045 & 0.24 & & - \\
\hline 23.000 & 8.283 & 8.293 & 8.301 & 0.018 & 0.0002 & 0.0104 & 0.02 & & - \\
\hline 23.500 & 8.669 & 8.629 & 8.662 & 0.040 & 0.0013 & 0.0197 & 0.07 & & - \\
\hline 24.000 & 9.166 & 9.020 & 9.075 & 0.146 & 0.0163 & 0.0229 & 0.71 & & - \\
\hline 24.500 & 9.709 & 9.465 & 9.521 & 0.244 & 0.0487 & 0.0175 & 2.78 & & - \\
\hline 25.000 & 10.219 & 9.943 & 10.092 & 0.276 & 0.0573 & 0.0179 & 3.20 & & - \\
\hline 25.500 & 10.686 & 10.457 & 10.501 & 0.229 & 0.0440 & 0.0116 & 3.79 & & \\
\hline 26.000 & 11.093 & 11.003 & 10.880 & 0.213 & 0.0096 & 0.0136 & 0.71 & & - \\
\hline 26.500 & 11.383 & 11.506 & 11.300 & 0.206 & 0.0169 & 0.0157 & 1.08 & & - \\
\hline $\begin{array}{r}27.000 \\
\mathrm{~mm} .\end{array}$ & $\begin{array}{r}11.747 \\
\mathrm{~mm} .\end{array}$ & $\begin{array}{r}11.954 \\
\mathrm{~mm} .\end{array}$ & $\begin{array}{r}11.780 \\
\mathrm{~mm} .\end{array}$ & $\begin{array}{c}0.207 \\
\mathrm{~mm} .\end{array}$ & 0.0373 & 0.0262 & 1.42 & & - \\
\hline
\end{tabular}

矢状面上で中心位を通る位置 $(\mathrm{Y}=8.729 \mathrm{~mm})$ より外 側の $\mathrm{Y}=11.000 \mathrm{~mm}$ の線上で $200 \mu$ 以下のばらつきを 示したのは， $\mathrm{P}_{1}$ で前方䄪 $4.0 \mathrm{~mm}$ まで (図 12), $\mathrm{P}_{2}$ で 前方約 $3.5 \mathrm{~mm}$ まで (図 13), $\mathrm{P}_{3}$ で前方約 $5.5 \mathrm{~mm}$ ま で（図 14）とであった.

(5) $\mathrm{Y}=13.000 \mathrm{~mm}$ (中心位より外側) 線上

矢状面上で中心位を通る位置 $(Y=8.729 \mathrm{~mm})$ より外 側の $\mathrm{Y}=13.000 \mathrm{~mm}$ の線上で $200 \mu$ 以下のばらつきを 示したのは, $\mathrm{P}_{1}$ で前方約 $2.5 \mathrm{~mm}$ まで (図 15), $\mathrm{P}_{2}$ で 前方約 $3.0 \mathrm{~mm}$ まで (図 16), $\mathrm{P}_{3}$ で前方約 $4.0 \mathrm{~mm}$ まで （図 17）とであった.

なお，図 3〜17 に示すようにいずれの矢状面図におい て中心位より後方では, すべての被験者において $200 \mu$ 以下のばらっきであった.

\section{(B) 前頭面}

（1） $\mathrm{X}=20.000 \mathrm{~mm}$ (中心位) を通る線上

中心位を通る $\mathrm{X}=20.000 \mathrm{~mm}$ の前頭面上では, $\mathrm{P}_{1}, \mathrm{P}_{2}$, $\mathrm{P}_{3}$ のいずれにおいてもそのばらつきは $200 \mu$ 以下であっ
た(図 18〜20).

(2) $\mathrm{X}=22.000 \mathrm{~mm}$ (中心位より前方) の線上 前頭面上で中心位を通る位置 $(X=20.000 \mathrm{~mm})$ より 前方の $\mathrm{X}=22.000 \mathrm{~mm}$ の線上で $200 \mu$ 以下のばらつき を示したのは，中心位より内側では， $\mathrm{P}_{1}, \mathrm{P}_{2}$ で約 $4.5 \mathrm{~mm}$ まで (図 21，22）， $P_{3}$ で約 $3.5 \mathrm{~mm}$ まで (図 23) とで あった. 中心位より外側では， $\mathrm{P}_{1}, \mathrm{P}_{2}, \mathrm{P}_{3}$ いずれの被験 者においても $5.5 \mathrm{~mm}$ まで（図 21〜23）であった.

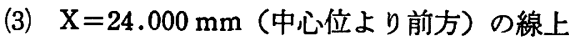

前頭面上で中心位を通る位置 $(X=20.000 \mathrm{~mm})$ より 前方の $\mathrm{X}=24.000 \mathrm{~mm}$ の線上で $200 \mu$ 以下のばらつき を示したのは, 中心位より内側では， $\mathrm{P}_{1}$ で約 $1.5 \mathrm{~mm}$, $\mathrm{P}_{3}$ で約 $2.5 \mathrm{~mm}$ までで, 中心位より外側では, $\mathrm{P}_{1}$ で約 $2.5 \mathrm{~mm}, \mathrm{P}_{3}$ で約 $4.5 \mathrm{~mm}$ までであったが, $\mathrm{P}_{2}$ では, 中 心位より内側と外側ではいずれも $200 \mu$ 以上のばらつき であった（図 24〜26）.

（4） $\mathrm{X}=19.000 \mathrm{~mm}$ (中心位より後方）の線上

前頭面上で中心位を通る位置 $(X=20.000 \mathrm{~mm})$ より 後方の $\mathrm{X}=19.000 \mathrm{~mm}$ の線上で $\mathrm{P}_{1}, \mathrm{P}_{2}, \mathrm{P}_{3}$ のいずれに 
表 3 被験者 $P_{1}$ について平面, 凸面, 凹面のプレートにおけるレジン フォッサのY 軸上でのZ座標の平均値と統計値

\begin{tabular}{|c|c|c|c|c|c|c|c|c|c|}
\hline \multirow{2}{*}{$\mathrm{X}$} & \multicolumn{3}{|c|}{ Z } & \multirow{2}{*}{ DT } & \multirow{2}{*}{$\mathrm{V}_{\mathrm{A}}$} & \multirow{2}{*}{$V_{E}$} & \multirow{2}{*}{ Fs } & \multirow{2}{*}{$F_{(1 \%)}^{(5 \%)}$} & \multirow{2}{*}{ 判定 } \\
\hline & $\mathrm{MA}_{\mathrm{A}}$ & $\mathrm{M}_{\mathrm{B}}$ & $M c$ & & & & & & \\
\hline 16.000 & 10.432 & 10.569 & 10.718 & 0.286 & 0.0614 & 0.0347 & 1.77 & $\begin{array}{l}<5.14 \\
<10.92\end{array}$ & \\
\hline 16.500 & 9.240 & 9.299 & 9.386 & 0.146 & 0.0163 & 0.0053 & 3.08 & & \\
\hline 17.000 & 8.578 & 8.621 & 8.686 & 0.108 & 0.0089 & 0.0026 & 3.42 & & \\
\hline 17.500 & 8.119 & 8.144 & 8.206 & 0.087 & 0.0060 & 0.0020 & 3.00 & & \\
\hline 18.000 & 7.792 & 7.796 & 7.847 & 0.055 & 0.0029 & 0.0014 & 2.07 & & \\
\hline 18.500 & 7.555 & 7.549 & 7.586 & 0.037 & 0.0012 & 0.0007 & 1.71 & & \\
\hline 19.000 & 7.389 & 7.372 & 7.401 & 0.029 & 0.0007 & 0.0007 & 1.00 & & \\
\hline 19.500 & 7.265 & 7.262 & 7.268 & 0.006 & 0.0001 & 0.0005 & 0.20 & & \\
\hline 20.000 & 7.201 & 7.196 & 7.197 & 0.005 & 0.0000 & 0.0000 & 0.00 & & \\
\hline 20.500 & 7.210 & 7.219 & 7.217 & 0.009 & 0.0000 & 0.0002 & 0.00 & & \\
\hline 21.000 & 7.258 & 7.283 & 7.257 & 0.026 & 0.0006 & 0.0004 & 1.50 & & \\
\hline 21.500 & 7.344 & 7.365 & 7.339 & 0.026 & 0.0003 & 0.0001 & 3.00 & & \\
\hline 22.000 & 7.464 & 7.507 & .7 .456 & 0.051 & 0.0023 & 0.0011 & 2.09 & & \\
\hline 22.500 & 7.632 & 7.727 & 7.688 & 0.095 & 0.0068 & 0.0020 & 3.40 & & \\
\hline 23.000 & 7.892 & 7.983 & 7.978 & 0.091 & 0.0079 & 0.0055 & 1.44 & & \\
\hline 23.500 & 8.210 & 8.216 & 8.316 & 0.106 & 0.0107 & 0.0094 & 1.14 & & \\
\hline 24.000 & 8.628 & 8.569 & 8.690 & 0.121 & 0.0111 & 0.0175 & 0.63 & & \\
\hline 24.500 & 8.875 & 8.985 & 9.113 & 0.238 & 0.0169 & 0.0245 & 0.69 & & \\
\hline 25.000 & 9.593 & 9.461 & 9.586 & 0.132 & 0.0163 & 0.0213 & 0.77 & & \\
\hline 25.500 & 10.077 & 9.962 & 10.090 & 0.128 & 0.0149 & 0.0179 & 0.83 & & \\
\hline 26.000 & 10.494 & 10.562 & 10.664 & 0.170 & 0.0047 & 0.0230 & 0.20 & & \\
\hline 26.500 & 10.868 & 11.053 & 10.972 & 0.185 & 0.0258 & 0.0293 & 0.88 & & \\
\hline 27.000 & 11.232 & 11.512 & 11.329 & 0.280 & 0.0608 & 0.0255 & 2.38 & & \\
\hline 27.500 & 11.557 & 11.905 & 11.744 & 0.348 & 0.0910 & 0.0293 & 3.11 & & \\
\hline $\begin{array}{c}28.000 \\
\mathrm{~mm} .\end{array}$ & $\begin{array}{r}11.847 \\
\mathrm{~mm} .\end{array}$ & $\begin{array}{c}12.202 \\
\mathrm{~mm} .\end{array}$ & $\begin{array}{c}12.059 \\
\mathrm{~mm}\end{array}$ & $\begin{array}{r}0.355 \\
\mathrm{~mm}\end{array}$ & 0.0857 & 0.0184 & 4.44 & & \\
\hline
\end{tabular}

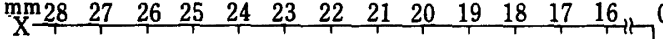

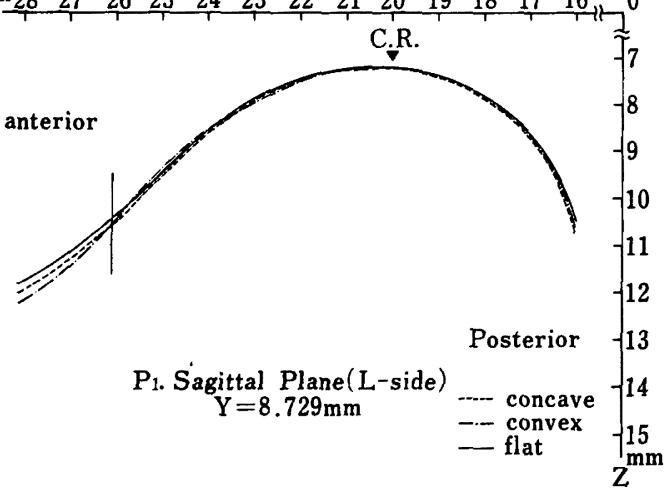

図 3 被験者 $P_{1}$ におおける C.B.P. の形態の差による レジンフォッサの平均値（矢状面）

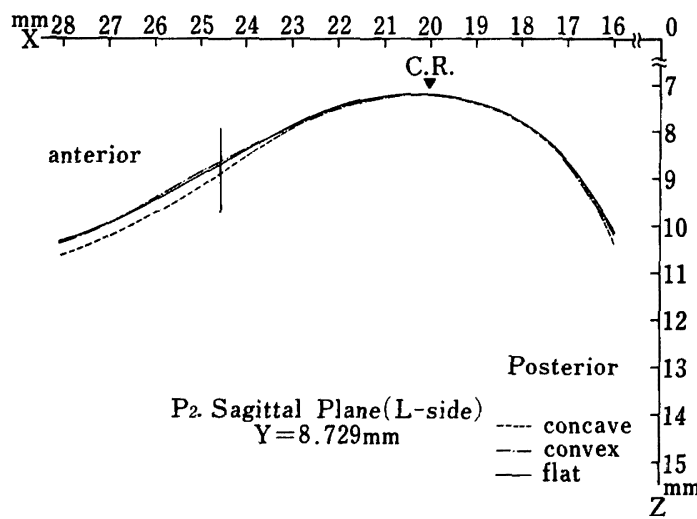

図 4 被験者 $\mathrm{P}_{2}$ における C.B.P. の形態の差による レジンフォッサの平均值 (矢状面) 
表 4 被験者 $\mathrm{P}_{1}$ について平面, 凸面, 凹面のプレートにおけるレジン フォッサのY軸上での Z 座標の平均値と統計値

\begin{tabular}{|c|c|c|c|c|c|c|c|c|c|}
\hline \multirow{2}{*}{$x$} & \multicolumn{3}{|c|}{ Z } & \multirow{2}{*}{$\mathrm{DT}_{\mathrm{T}}$} & \multirow{2}{*}{$V_{A}$} & \multirow{2}{*}{$V_{E}$} & \multirow{2}{*}{$F_{S}$} & \multirow{2}{*}{$F\left(\begin{array}{l}5 \%) \\
(1 \%)\end{array}\right.$} & \multirow{2}{*}{ 判定 } \\
\hline & $\mathrm{M}_{\mathrm{A}}$ & $M_{B}$ & $\mathrm{Mc}$ & & & & & & \\
\hline 16.500 & 9.765 & 9.905 & 9.956 & 0.191 & 0.0295 & 0.0064 & 4.61 & $\begin{array}{r}<5.14 \\
<10.92\end{array}$ & \\
\hline 17.000 & 8.991 & 9.085 & 9.111 & 0.120 & 0.0120 & 0.0034 & 3.53 & & \\
\hline 17.500 & 8.477 & 8.538 & 8.529 & 0.061 & 0.0032 & 0.0061 & 2.00 & & \\
\hline 18.000 & 8.116 & 8.152 & 8.145 & 0.036 & 0.0011 & 0.0014 & 0.79 & & \\
\hline 18.500 & 7.849 & 7.867 & 7.858 & 0.018 & 0.0003 & 0.0014 & 0.21 & & \\
\hline 19.000 & 7.659 & 7.667 & 7.653 & 0.014 & 0.0001 & 0.0015 & 0.07 & & \\
\hline 19.500 & 7.552 & 7.546 & 7.526 & 0.026 & 0.0005 & 0.0021 & 0.24 & & \\
\hline 20.000 & 7.501 & 7.484 & 7.464 & 0.037 & 0.0011 & 0.0022 & 0.50 & & \\
\hline 20.500 & 7.511 & 7.472 & 7.460 & 0.051 & 0.0022 & 0.0021 & 1.05 & & \\
\hline 21.000 & 7.578 & 7.530 & 7.519 & 0.059 & 0.0030 & 0.0021 & 1.43 & & \\
\hline 21.500 & 7.680 & 7.668 & 7.641 & 0.039 & 0.0012 & 0.0016 & 0.75 & & \\
\hline 22.000 & 7.827 & 7.851 & 7.827 & 0.024 & 0.0006 & 0.0010 & 0.60 & & \\
\hline 22.500 & 8.050 & 8.075 & 8.071 & 0.025 & 0.0006 & 0.0034 & 0.18 & & \\
\hline 23.000 & 8.345 & 8.333 & 8.388 & 0.055 & 0.0026 & 0.0100 & 0.26 & & \\
\hline 23.500 & 8.724 & 8.646 & 8.739 & 0.093 & 0.0076 & 0.0119 & 0.63 & & \\
\hline 24.000 & 9.261 & 9.012 & 9.211 & 0.249 & 0.0518 & 0.0162 & 3.20 & & \\
\hline 24.500 & 9.746 & 9.447 & 9.652 & 0.299 & 0.0703 & 0.0220 & 3.20 & & \\
\hline 25.000 & 10.238 & 9.960 & 10.137 & 0.332 & 0.0858 & 0.0230 & 3.73 & & \\
\hline 25.500 & 10.623 & 10.430 & 10.615 & 0.193 & 0.0358 & 0.0186 & 1,93 & & \\
\hline 26.000 & 10.999 & 10.921 & 11.062 & 0.141 & 0.0151 & 0.0250 & 0.60 & & \\
\hline 26.500 & 11.357 & 11.389 & 11.371 & 0.032 & 0.0008 & 0.0201 & 0.04 & & \\
\hline 27.000 & 11.686 & 11.762 & 11.712 & 0.076 & 0.0045 & 0.0183 & 0.25 & & \\
\hline $\mathrm{mm}$. & $\mathrm{mm}$. & $\mathrm{mm}$. & & $\mathrm{mm}$ & & & & & \\
\hline
\end{tabular}

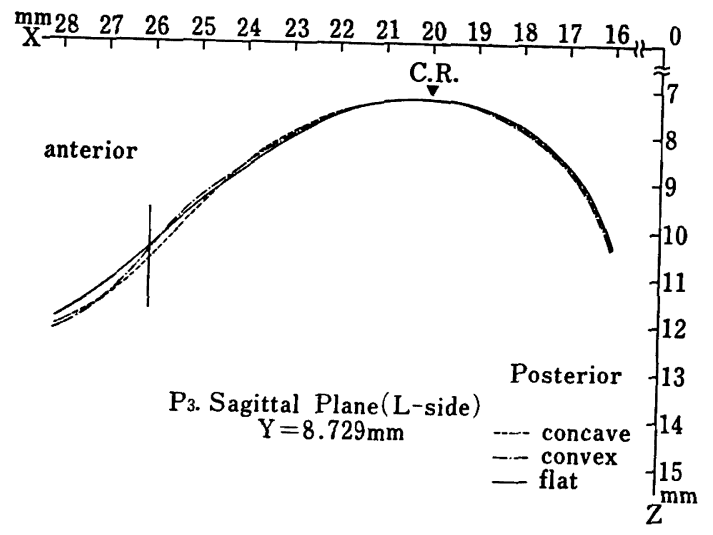

図 5 被験者 $\mathrm{P}_{3}$ における C.B.P. の形態の差による レジンフォッサの平均值 (矢状面)

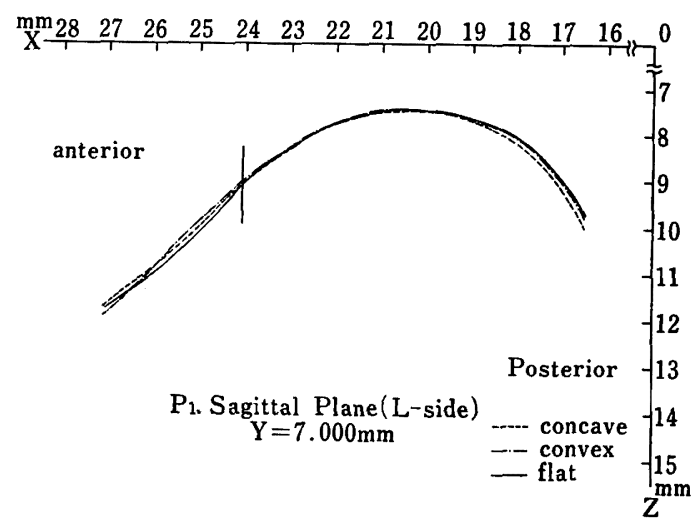

図 6 被験者 $\mathrm{P}_{1}$ におおる C.B.P.の形態の差による レジンフォッサの平均值 (矢状面) 
表 5 被験者 $\mathrm{P}_{1}$ について平面, 凸面, 凹面のプレートにおけるレジン フォッサのY 軸上での Z 座標の平均値と統計值

\begin{tabular}{|c|c|c|c|c|c|c|c|c|c|}
\hline \multirow{2}{*}{$X$} & \multicolumn{3}{|c|}{ Z } & \multirow{2}{*}{ Dr } & \multirow{2}{*}{$V_{A}$} & \multirow{2}{*}{$V_{E}$} & \multirow{2}{*}{$F_{s}$} & \multirow{2}{*}{$F_{(1 \%)}^{(5 \%)}$} & \multirow{2}{*}{ 判定 } \\
\hline & $\mathrm{M}_{\mathrm{A}}$ & $\mathrm{MB}_{\mathrm{B}}$ & $\mathrm{Mc}$ & & & & & & \\
\hline 17.500 & 10.423 & 10.362 & 10.357 & 0.066 & 0.0040 & 0.0049 & 0.82 & $\begin{array}{r}5.14 \\
<10.92\end{array}$ & \\
\hline 18.000 & 9.536 & 9.579 & 9.569 & 0.043 & 0.0015 & 0.0042 & 0.36 & & \\
\hline 18.500 & 9.104 & 9.115 & 9.107 & 0.011 & 0.0001 & 0.0036 & 0.03 & & \\
\hline 19.000 & 8.847 & 8.814 & 8.819 & 0.033 & 0.0010 & 0.0040 & 0.25 & & \\
\hline 19.500 & 8.694 & 8.647 & 8.641 & 0.053 & 0.0026 & 0.0040 & 0.65 & & \\
\hline 20.000 & 8.631 & 8.572 & 8.560 & 0.071 & 0.0044 & 0.0041 & 1.07 & & \\
\hline 20.500 & 8.632 & 8.564 & 8.558 & 0.074 & 0.0052 & 0.0042 & 1.42 & & \\
\hline 21.000 & 8.716 & 8.633 & 8.616 & 0.100 & 0.0088 & 0.0044 & 2.00 & & \\
\hline 21.500 & 8.849 & 8.817 & 8.802 & 0.047 & 0.0018 & 0.0031 & 0.58 & & \\
\hline 22.000 & 9.065 & 9.054 & 9.067 & 0.013 & 0.0001 & 0.0070 & 0.01 & & \\
\hline 22.500 & 9.429 & 9.306 & 9.386 & 0.123 & 0.0117 & 0.0115 & 1.02 & & - \\
\hline 23.000 & 9.836 & 9.610 & 9.716 & 0.226 & 0.0384 & 0.0119 & 3.23 & & \\
\hline 23.500 & 10.239 & 9.994 & 10.078 & 0.245 & 0.0466 & 0.0118 & 3.95 & & \\
\hline 24.000 & 10.678 & 10.429 & 10.543 & 0.249 & 0.0468 & 0.0141 & 3.32 & & \\
\hline 24.500 & 11.083 & 10.901 & 11.028 & 0.172 & 0.0264 & 0.0145 & 1.82 & & $-\cdots$ \\
\hline $\begin{array}{r}25.000 \\
\mathrm{~mm} .\end{array}$ & $\begin{array}{c}11.471 \\
\mathrm{~mm} .\end{array}$ & $\begin{array}{r}11.366 \\
\mathrm{~mm} .\end{array}$ & $\begin{array}{r}11.491 \\
\mathrm{~mm} .\end{array}$ & $\begin{array}{r}0.125 \\
\mathrm{~mm}\end{array}$ & 0.0136 & 0.0141 & 0.97 & & - \\
\hline
\end{tabular}

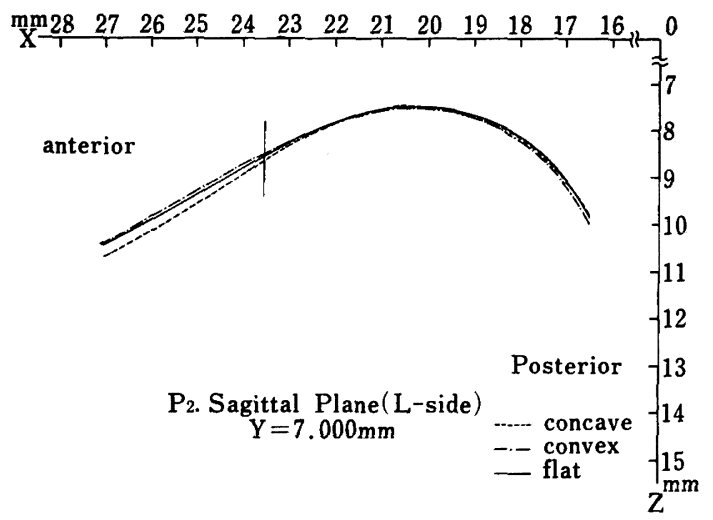

図 7 被験者 $\mathrm{P}_{2}$ における C.B.P. の形態の差による レジンフォッサの平均值 (矢状面)

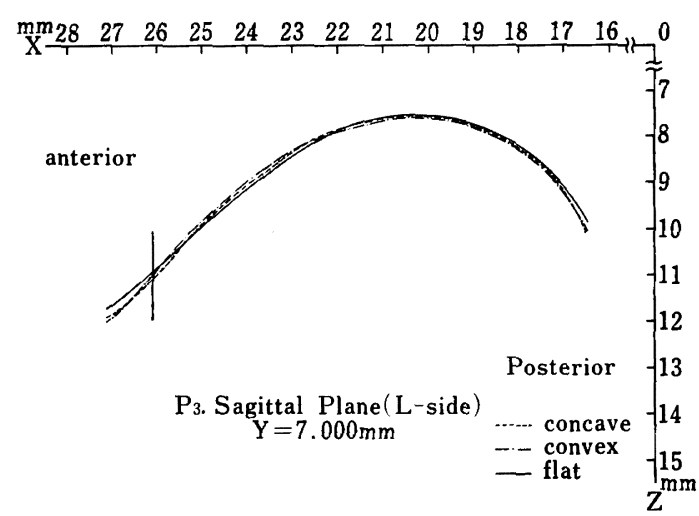

図 8 被験者 $\mathrm{P}_{3}$ における C.B.P.の形態の差による レジンフォッサの平均值 (矢状面) 
表 6 被験者 $\mathrm{P}_{2}$ について平面, 凸面, 凹面のプレートにおけるレジン フォッサのY蚰上での Z 座標の平均値と統計值

\begin{tabular}{|c|c|c|c|c|c|c|c|c|c|}
\hline \multirow{2}{*}{$\mathrm{X}$} & \multicolumn{3}{|c|}{$Z$} & \multirow{2}{*}{ DT } & \multirow{2}{*}{$\mathrm{VA}_{\mathrm{A}}$} & \multirow{2}{*}{$V_{E}$} & \multirow{2}{*}{ Fs } & \multirow{2}{*}{$F_{(1 \%)}^{(5 \%)}$} & \multirow{2}{*}{ 判定 } \\
\hline & $M_{A}$ & $\mathrm{MB}_{\mathrm{B}}$ & $\mathrm{Mc}_{\mathrm{C}}$ & & & & & & \\
\hline 17.000 & 10.904 & 10.853 & 10.851 & 0.053 & 0.0027 & 0.0428 & 0.06 & $\begin{array}{r}<5.14 \\
<10.92\end{array}$ & \\
\hline 17.500 & 9.929 & 9.900 & 9.998 & 0.098 & 0.0076 & 0.0331 & 0.23 & & \\
\hline 18.000 & 9.450 & 9.462 & 9.402 & 0.060 & 0.0030 & 0.0118 & 0.25 & & \\
\hline 18.500 & 9.056 & 9.077 & 9.017 & 0.060 & 0.0028 & 0.0048 & 0.58 & & \\
\hline 19.000 & 8.790 & 8.830 & 8.765 & 0.065 & 0.0033 & 0.0032 & 1.03 & & \\
\hline 19.500 & 8.625 & 8.669 & 8.603 & 0.066 & 0.0034 & 0.0028 & 1.21 & & \\
\hline 20.000 & 8.545 & 8.591 & 8.531 & 0.060 & 0.0029 & 0.0022 & 1.32 & & \\
\hline 20.500 & 8.540 & 8.589 & 8.537 & 0.052 & 0.0026 & 0.0031 & 0.84 & & \\
\hline 21.000 & 8.616 & 8.657 & 8.634 & 0.041 & 0.0013 & 0.0046 & 0.28 & & \\
\hline 21.500 & 8.786 & 8.814 & 8.802 & 0.031 & 0.0006 & 0.0079 & 0.08 & & \\
\hline 22.000 & 9.046 & 9.030 & 9.052 & 0.022 & 0.0004 & 0.0129 & 0.03 & & \\
\hline 22.500 & 9.359 & 9.271 & 9.359 & 0.088 & 0.0078 & 0.0175 & 0.45 & & \\
\hline 23.000 & 9.672 & 9.532 & 9.716 & 0.184 & 0.0277 & 0.0194 & 1.43 & & \\
\hline 23.500 & 9.944 & 9.805 & 10.072 & 0.267 & 0.0535 & 0.0204 & 2.62 & & \\
\hline 24.000 & 10.208 & 10.090 & 10.390 & 0.300 & 0.0687 & 0.0214 & 3.21 & & \\
\hline 24.500 & 10.481 & 10.418 & 10.686 & 0.268 & 0.0589 & 0.0202 & 2.92 & & \\
\hline $\begin{array}{c}25.000 \\
\mathrm{~mm} .\end{array}$ & $\begin{array}{r}10.771 \\
\mathrm{~mm} .\end{array}$ & $\begin{array}{c}10.746 \\
\mathrm{~mm} .\end{array}$ & $\begin{array}{c}10.996 \\
\mathrm{~mm} .\end{array}$ & $\begin{array}{r}0.250 \\
\mathrm{~mm} .\end{array}$ & 0.0566 & 0.0233 & 2.54 & & \\
\hline
\end{tabular}

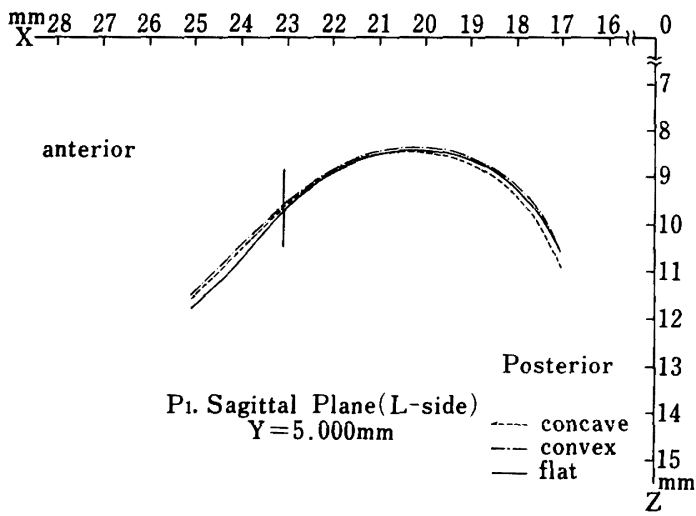

図 9 被験者 $\mathrm{P}_{1}$ における C.B.P. の形態の差による レジンフォッサの平均俌（知状面）

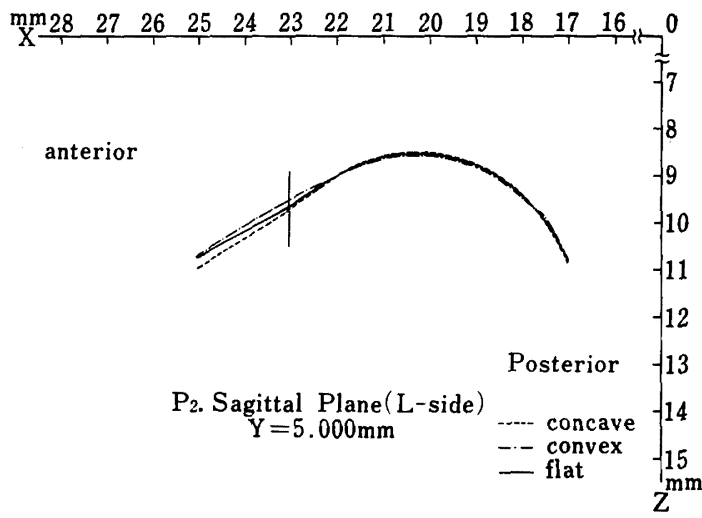

図 10 被験者 $\mathrm{P}_{2}$ におおける C.B.P. の形態の差による レジンフォッサの平均值 (矢状面) 
表 7 被験者 $\mathrm{P}_{2}$ について平面, 凸面, 凹面のプレートにおけるレジン フォッサのY軸上でのZ㻨標の平均値と統計值

\begin{tabular}{|c|c|c|c|c|c|c|c|c|c|}
\hline \multirow{2}{*}{$\mathrm{X}$} & \multicolumn{3}{|c|}{ Z } & \multirow{2}{*}{$\mathrm{DT}$} & \multirow{2}{*}{$\mathrm{V}_{\mathrm{A}}$} & \multirow{2}{*}{$V_{E}$} & \multirow{2}{*}{ Fs } & \multirow{2}{*}{$F_{(1 \%)}^{(5 \%)}$} & \multirow{2}{*}{ 判定: } \\
\hline & $\mathrm{MA}_{\mathrm{A}}$ & $\mathrm{MB}_{\mathrm{B}}$ & $\mathrm{M}_{\mathrm{C}}$ & & & & & & \\
\hline 16.500 & 9.811 & 9.964 & 9.783 & 0.181 & 0.0287 & 0.0407 & 0.71 & $\begin{array}{l}<5.14 \\
<10.92\end{array}$ & \\
\hline 17.000 & 9.024 & 9.148 & 9.081 & 0.124 & 0.0116 & 0.0236 & 0.49 & & \\
\hline 17.500 & 8.512 & 8.601 & 8.547 & 0.089 & 0.0061 & 0.0121 & 0.50 & & \\
\hline 18.000 & 8.131 & 8.205 & 8.161 & 0.074 & 0.0043 & 0.0062 & 0.69 & & \\
\hline 18.500 & 7.851 & 7.923 & 7.877 & 0.072 & 0.0040 & 0.0041 & 0.98 & & \\
\hline 19.000 & 7.650 & 7.714 & 7.682 & 0.064 & 0.0031 & 0.0022 & 1.41 & & \\
\hline 19.500 & 7.542 & 7.590 & 7.558 & 0.048 & 0.0018 & 0.0015 & 1.20 & & \\
\hline 20.000 & 7.492 & 7.519 & 7.496 & 0.027 & 0.0006 & 0.0012 & 0.50 & & \\
\hline 20.500 & 7.487 & 7.526 & 7.443 & 0.083 & 0.0052 & 0.0032 & 1.63 & & \\
\hline 21.000 & 7.537 & 7.568 & 7.546 & 0.031 & 0.0008 & 0.0019 & 0.42 & & \\
\hline 21.500 & 7.636 & 7.672 & 7.656 & 0.036 & 0.0010 & 0.0026 & 0.39 & & \\
\hline $22 \vdots 000$ & 7.810 & 7.828 & 7.822 & 0.018 & 0.0003 & 0.0041 & 0.07 & & \\
\hline 22.500 & 8.031 & 8.029 & 8.051 & 0.022 & 0.0005 & 0.0077 & 0.07 & & \\
\hline 23.000 & 8.297 & 8.252 & 8.323 & 0.071 & 0.0039 & 0.0124 & 0.31 & & \\
\hline 23.500 & 8.570 & 8.487 & 8.635 & 0.148 & 0.0165 & 0.0163 & 1.01 & & \\
\hline 24.000 & 8.836 & 8.738 & 8.981 & 0.243 & 0.0451 & 0.0190 & 2.37 & & \\
\hline 24.500 & 9.100 & 9.001 & 9.305 & 0.304 & 0.0720 & 0.0180 & 4.00 & & \\
\hline 25.000 & 9.376 & 9.290 & 9.599 & 0.309 & 0.0764 & 0.0187 & 4.09 & & \\
\hline 25.500 & 9.653 & 9.600 & 9.909 & 0.309 & 0.0822 & 0.0257 & 3.20 & & \\
\hline 26.000 & 9.930 & 9.899 & 10.194 & 0.295 & 0.0791 & 0.0255 & 3.10 & & \\
\hline 26.500 & 10.207 & 10.175 & 10.459 & 0.284 & 0.0726 & 0.0218 & 3.33 & & \\
\hline 27.000 & 10.461 & 10.424 & 10.702 & 0.278 & 0.0682 & 0.0231 & 2.95 & & \\
\hline & & & & & & & & & \\
\hline
\end{tabular}

anterior

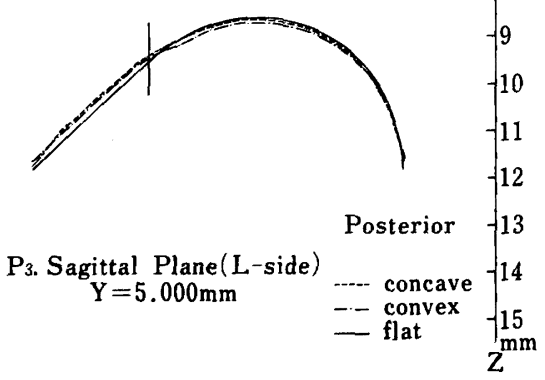

图 11 被験者 $\mathrm{P}_{3}$ における C.B.P.の形態の差による レジンフォッサの平均值（知状面）

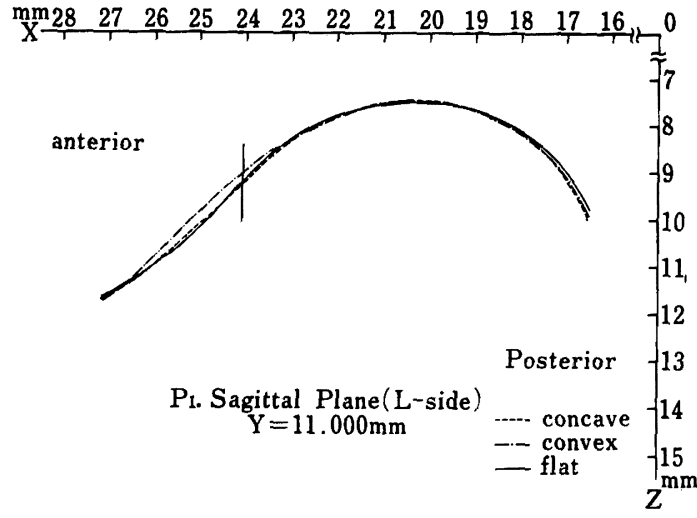

図 12 被験者 $\mathrm{P}_{1}$ における C.B.P.の形態の差による レジンフォッサの平均值 (矢状面) 
表 8 被験者 $\mathrm{P}_{2}$ について平面, 凸面, 凹面のプレートにおけるレジン フォッサのY軸上での $Z$ 座標の平均値と統計值

\begin{tabular}{|c|c|c|c|c|c|c|c|c|c|}
\hline \multirow{2}{*}{$X$} & \multicolumn{3}{|c|}{$\mathrm{Z}$} & \multirow{2}{*}{$\mathrm{DT}_{\mathrm{T}}$} & \multirow{2}{*}{$\mathrm{V}_{\mathrm{A}}$} & \multirow{2}{*}{$V_{E}$} & \multirow{2}{*}{$\mathrm{Fs}$} & \multirow{2}{*}{$F_{(1 \%)}^{(5 \%)}$} & \multirow{2}{*}{ 判定 } \\
\hline & $\mathrm{M}_{\mathrm{A}}$ & $\mathrm{MB}_{\mathrm{B}}$ & $\mathrm{Mc}$ & & & & & & \\
\hline 16.0 .00 & 10.449 & 10.672 & 10.415 & 0.257 & 0.0583 & 0.0670 & 0.87 & $\begin{array}{l}<5.14 \\
<10.92\end{array}$ & \\
\hline 16.500 & 9.299 & 9.380 & 9.335 & 0.081 & 0.0049 & 0.0471 & 0.10 & & \\
\hline 17.000 & 8.609 & 8.696 & 8.640 & 0.087 & 0.0059 & 0.0251 & 0.24 & & \\
\hline 17.500 & 8.138 & 8.209 & 8.169 & 0.071 & 0.0038 & 0.0130 & 0.29 & & \\
\hline 18.000 & 7.786 & 7.848 & 7.822 & 0.062 & 0.0030 & 0.0076 & 0.40 & & \\
\hline 18.500 & 7.533 & 7.588 & 7.565 & 0.055 & 0.0023 & 0.0041 & 0.56 & & \\
\hline 19.000 & 7.352 & 7.409 & 7.386 & 0.057 & 0.0026 & 0.0025 & 1.04 & & \\
\hline 19.500 & 7.284 & 7.292 & 7.270 & 0.022 & 0.0004 & 0.0009 & 0.44 & & \\
\hline 20.000 & 7.208 & 7.209 & 7.209 & 0.001 & 0.0001 & 0.0003 & 0.33 & & \\
\hline 20.500 & 7.219 & 7.223 & 7.197 & 0.026 & 0.0006 & 0.0004 & 1.50 & & \\
\hline 21.000 & 7.249 & 7.285 & 7.252 & 0.036 & 0.0012 & 0.0006 & 2.00 & & \\
\hline 21.500 & 7.324 & 7.366 & 7.342 & 0.042 & 0.0014 & 0.0009 & 1.56 & & \\
\hline 22.000 & 7.467 & 7.498 & 7.508 & 0.041 & 0.0014 & 0.0034 & 0.41 & & \\
\hline 22.500 & 7.681 & 7.681 & 7.710 & 0.029 & 0.0008 & 0.0080 & 0.29 & & \\
\hline 23.000 & 7.924 & 7.909 & 7.960 & 0.051 & 0.0021 & 0.0108 & 0.19 & & \\
\hline 23.500 & 8.177 & 8.140 & 8.252 & 0.112 & 0.0098 & 0.0154 & 0.64 & & \\
\hline 24.000 & 8.440 & 8.385 & 8.592 & 0.207 & 0.0346 & 0.0201 & 1.72 & & \\
\hline 24.500 & 8.709 & 8.644 & 8.914 & 0.270 & 0.0596 & 0.0215 & 2.77 & & \\
\hline 25.000 & 8.977 & 8.913 & 9.213 & 0.300 & 0.0747 & 0.0224 & 3.34 & & \\
\hline 25.500 & 9.239 & 9.197 & 9.506 & 0.309 & 0.0842 & 0.0254 & 3.32 & & \\
\hline 26.000 & 9.510 & 9.477 & 9.784 & 0.307 & 0.0855 & 0.0244 & 3.50 & & \\
\hline 26.500 & 9.788 & 9.755 & 10.042 & 0.287 & 0.0738 & 0.0238 & 3.10 & & \\
\hline 27.000 & 10.040 & 10.019 & 10.301 & 0.282 & 0.0739 & 0.0258 & 2.86 & & \\
\hline 27.500 & 10.230 & 10.233 & 10.501 & 0.271 & 0.0727 & 0.0324 & 2.24 & & \\
\hline $\begin{array}{c}28.000 \\
\mathrm{~mm} .\end{array}$ & $\begin{array}{c}10.389 \\
\mathrm{~mm} .\end{array}$ & $\begin{array}{c}10.388 \\
\mathrm{~mm} .\end{array}$ & $\begin{array}{c}10.668 \\
\mathrm{~mm} .\end{array}$ & $\begin{array}{r}0.280 \\
\mathrm{~mm} .\end{array}$ & 0.0779 & 0.0310 & 2.51 & & \\
\hline
\end{tabular}

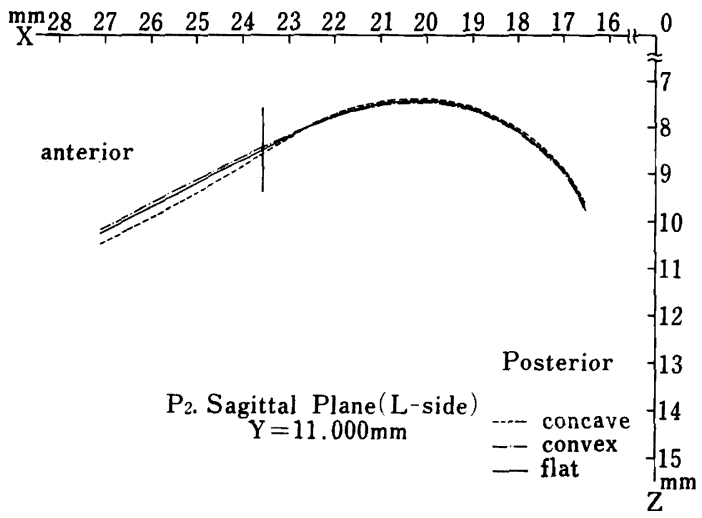

図 13 被験者 $\mathrm{P}_{2}$ における C.B.P.の形態の差による レジンフォッサの平均值 (矢状面)

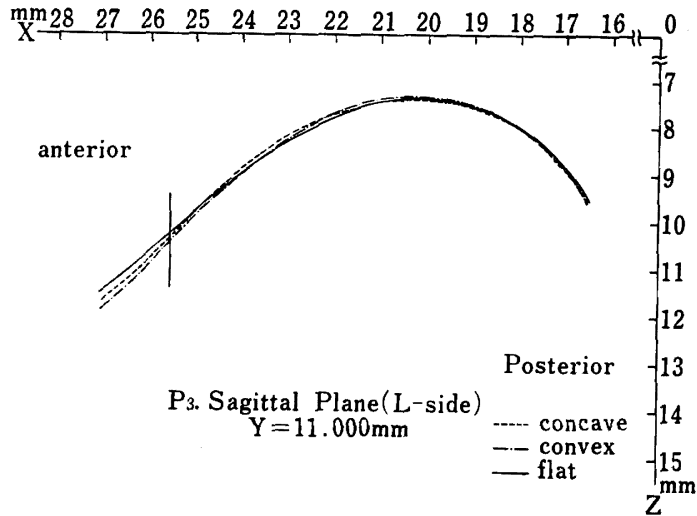

図 14 被験者 $\mathrm{P}_{3}$ にお计る C.B.P.の形態の差による レジンフォッサの平均値 (矢状面) 
表 9 被験者 $\mathrm{P}_{2}$ について平面, 凸面, 凹面のプレートにおけるレジン フォッサの $\mathrm{Y}$ 軸上での $\mathrm{Z}$ 座標の平均值と統計值

\begin{tabular}{|c|c|c|c|c|c|c|c|c|c|}
\hline \multirow{2}{*}{$X$} & \multicolumn{3}{|c|}{ Z } & \multirow{2}{*}{ DT } & \multirow{2}{*}{$V_{i}$} & \multirow{2}{*}{$V_{E}$} & \multirow{2}{*}{ Fs } & \multirow{2}{*}{$\mathrm{F}_{(1 \%)}^{(5 \%)}$} & \multirow{2}{*}{ 判定 } \\
\hline & $M_{A}$ & $M_{B}$ & $M_{c}$ & & & & & & \\
\hline 16.500 & 9.675 & 9.786 & 9.679 & 0.111 & 0.0119 & 0.0921 & 0.21 & $<5.14$ & \\
\hline 17.000 & 8.917 & 8.991 & 8.910 & 0.081 & 0.0062 & 0.0358 & 0.17 & & \\
\hline 17.500 & 8.405 & 8.474 & 8.402 & 0.072 & 0.0050 & 0.0175 & 0.29 & & \\
\hline 18.000 & 8.038 & 8.097 & 8.038 & 0.059 & 0.0036 & 0.0113 & 0.32 & & \\
\hline 18.500 & 7.772 & 7.827 & 7.769 & 0.058 & 0.0032 & 0.0069 & 0.46 & & \\
\hline 19.000 & 7.583 & 7.629 & 7.577 & 0.052 & 0.0025 & 0.0045 & 0.56 & & \\
\hline 19.500 & 7.468 & 7.513 & 7.460 & 0.053 & 0.0025 & 0.0026 & 0.96 & & \\
\hline 20.000 & 7.427 & 7.463 & 7.410 & 0.053 & 0.0022 & 0.0014 & 1.57 & & \\
\hline 20.500 & 7.430 & 7.469 & 7.410 & 0.059 & 0.0028 & 0.0012 & 2.33 & & \\
\hline 21.000 & 7.495 & 7.535 & 7.468 & 0.067 & 0.0034 & 0.0015 & 2.27 & & \\
\hline 21.500 & 7.614 & 7.654 & 7.588 & 0.066 & 0.0033 & 0.0023 & 1.44 & & \\
\hline 22.000 & 7.784 & 7.784 & 7.761 & 0.023 & 0.0006 & 0.0049 & 0.12 & & \\
\hline 22.500 & 7.997 & 7.971 & 7.985 & 0.026 & 0.0006 & 0.0073 & 0.08 & & \\
\hline 23.000 & 8.227 & 8.181 & 8.256 & 0.075 & 0.0043 & 0.0111 & 0.39 & & \\
\hline 23.500 & 8.474 & 8.414 & 8.568 & 0.154 & 0.0180 & 0.0167 & 1.08 & & \\
\hline 24.000 & 8.737 & 8.655 & 8.881 & 0.226 & 0.0392 & 0.0202 & 1.94 & & \\
\hline 24.500 & 8.984 & 8.903 & 9.182 & 0.279 & 0.0616 & 0.0215 & 2.87 & & \\
\hline 25.000 & 9.245 & 9.163 & 9.465 & 0.302 & 0.0732 & 0.0227 & 3.23 & & \\
\hline 25.500 & 9.503 & 9.431 & 9.744 & 0.313 & 0.0806 & 0.0213 & 3.78 & & \\
\hline 26.000 & 9.775 & 9.712 & 10.010 & 0.298 & 0.0739 & 0.0217 & 3.41 & & \\
\hline 26.500 & 10.048 & 9.972 & 10.270 & 0.298 & 0.0721 & 0.0209 & 3.45 & & \\
\hline 27.000 & 10.272 & 10.217 & 10.510 & 0.293 & 0.0727 & 0.0265 & 2.74 & & \\
\hline $\mathrm{mm}$. & $\mathrm{mm}$. & $\mathrm{mm}$. & $\mathrm{mm}$. & $\mathrm{mm}$. & & & & & \\
\hline
\end{tabular}

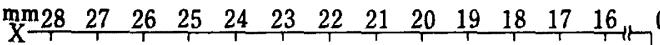

anterior

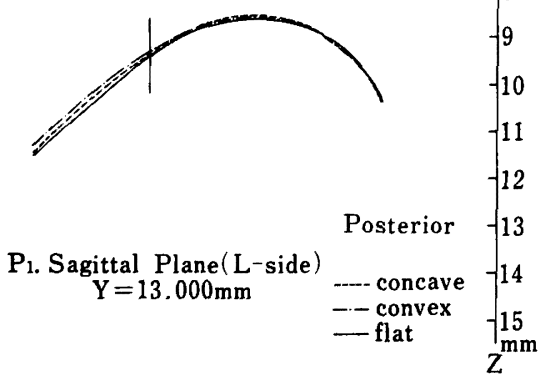

図 15 被㰸者 $\mathrm{P}_{1}$ における C.B.P. の形態の差による レジンフォッサの平均値（矢状面）

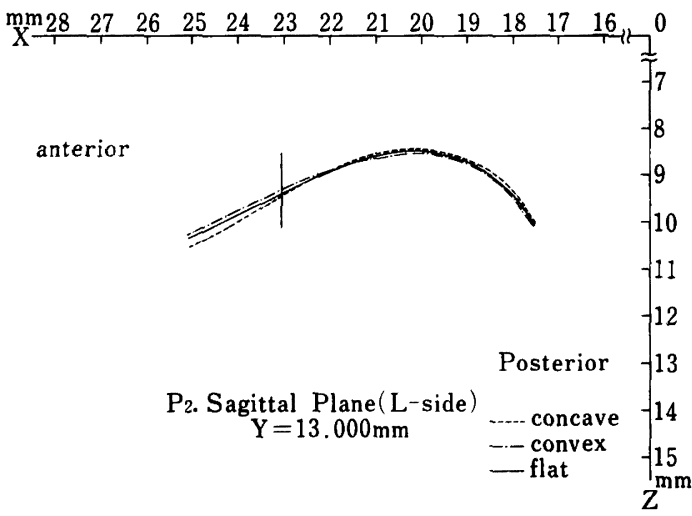

図 16 被験者 $\mathrm{P}_{2}$ における C.B.P. の形態の差による レジンフォッサの平均值（矢状面） 
表 10 被験者 $\mathrm{P}_{2}$ について平面, 凸面, 凹面のプレートにおけるレジン フォッサのY 軸上での Z 座僄の平均值と統計值

\begin{tabular}{|c|c|c|c|c|c|c|c|c|c|}
\hline \multirow{2}{*}{$X$} & \multicolumn{3}{|c|}{$Z$} & \multirow{2}{*}{$\mathrm{DT}_{\mathrm{T}}$} & \multirow{2}{*}{$\mathrm{V}_{\mathrm{A}}$} & \multirow{2}{*}{$V_{E}$} & \multirow{2}{*}{$\mathrm{Fs}_{\mathrm{s}}$} & \multirow{2}{*}{$F_{(1 \%)}^{(5 \%)}$} & \multirow{2}{*}{ 判定 } \\
\hline & $\mathrm{M}_{\mathrm{A}}$ & $\mathrm{MB}_{\mathrm{B}}$ & $\mathrm{Mc}$ & & & & & & \\
\hline 17.500 & 10.073 & 10.082 & 9.968 & 0.114 & 0.0119 & 0.0935 & 0.13 & $\begin{array}{l}<5.14 \\
<10.92\end{array}$ & \\
\hline 18.000 & 9.388 & 9.390 & 9.290 & 0.100 & 0.0099 & 0.0307 & 0.32 & & \\
\hline 18.500 & 8.974 & 8.993 & 8.899 & 0.094 & 0.0074 & 0.0139 & 0.53 & & \\
\hline 19.000 & 8.705 & 8.732 & 8.638 & 0.094 & 0.0070 & 0.0079 & 0.89 & & \\
\hline 19.500 & 8.550 & 8.585 & 8.488 & 0.097 & 0.0073 & 0.0041 & 1.78 & & \\
\hline 20.000 & 8.486 & 8.523 & 8.421 & 0.102 & 0.0081 & 0.0027 & 3.00 & & \\
\hline 20.500 & 8.496 & 8.537 & 8.420 & 0.117 & 0.0105 & 0.0024 & 4.38 & & \\
\hline 21.000 & 8.593 & 8.625 & 8.504 & 0.121 & 0.0118 & 0.0034 & 3.47 & & \\
\hline 21.500 & 8.739 & 8.738 & 8.668 & 0.071 & 0.0050 & 0.0065 & 0.77 & & \\
\hline 22.000 & 8.933 & 8.889 & 8.891 & 0.044 & 0.0019 & 0.0111 & 0.17 & & \\
\hline 22.500 & 9.144 & 9.082 & 9.164 & 0.082 & 0.0055 & 0.0160 & 0.34 & & \\
\hline 23.000 & 9.373 & 9.307 & 9.446 & 0.139 & 0.0146 & 0.0203 & 0.72 & & \\
\hline 23.500 & 9.617 & 9.542 & 9.744 & 0.202 & 0.0313 & 0.0239 & 1.31 & & \\
\hline 24.000 & 9.853 & 9.777 & 10.023 & 0.246 & 0.0475 & 0.0237 & 2.00 & & \\
\hline 24.500 & 10.101 & 10.020 & 10.288 & 0.268 & 0.0568 & 0.0226 & 2.51 & & \\
\hline $\begin{array}{r}25.000 \\
\mathrm{~mm} .\end{array}$ & $\begin{array}{c}10.354 \\
\mathrm{~mm}\end{array}$ & $\begin{array}{c}10.268 \\
\mathrm{~mm} .\end{array}$ & $\begin{array}{c}10.565 \\
\mathrm{~mm} .\end{array}$ & $\begin{array}{r}0.297 \\
\mathrm{~mm}\end{array}$ & 0.0697 & 0.0238 & 2.93 & & \\
\hline
\end{tabular}

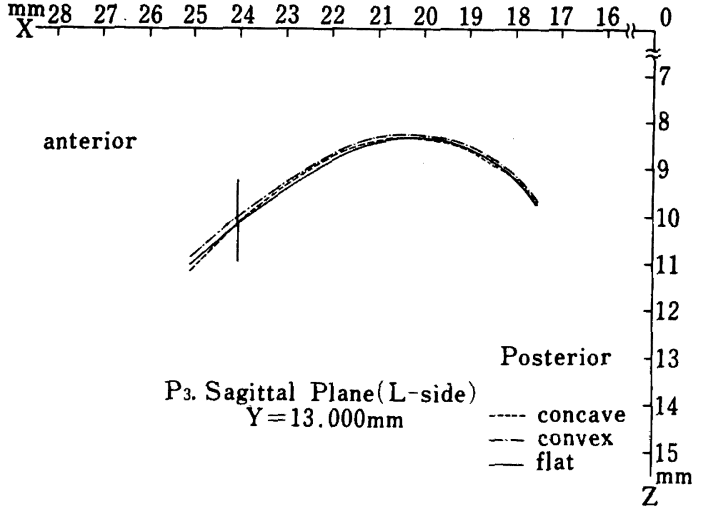

図 17 被験者 $\mathrm{P}_{3}$ における C.B.P. の形態の差による レジンフォッサの平均值 (矢状面)

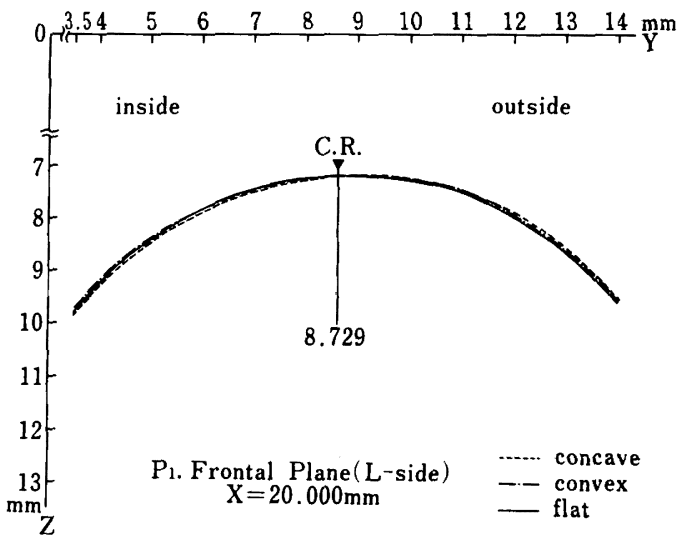

図 18 被験者 $\mathrm{P}_{1}$ における C.B.P. の形態の差による レジンフォッサの平均值（前頭面） 
表 11 被験者 $\mathrm{P}_{3}$ について平面, 凸面, 凹面のプレートにおけるレジン フォッサのY 軸上での Z 座標の平均值と統計値

\begin{tabular}{|c|c|c|c|c|c|c|c|c|c|}
\hline \multirow{2}{*}{$\mathrm{X}$} & \multicolumn{3}{|c|}{ Z } & \multirow{2}{*}{$\mathrm{DT}_{\mathrm{T}}$} & \multirow{2}{*}{$\mathrm{V}_{\mathrm{A}}$} & \multirow{2}{*}{$\mathrm{VE}_{\mathrm{E}}$} & \multirow{2}{*}{$\mathrm{Fs}$} & \multirow{2}{*}{$F_{(1 \%)}^{(5 \%)}$} & \multirow{2}{*}{ 判定 } \\
\hline & $\mathrm{M}_{\mathrm{A}}$ & $\mathrm{MB}_{\mathrm{B}}$ & $\mathrm{Mc}$ & & & & & & \\
\hline 17.000 & 11.719 & 11.630 & 11.749 & 0.119 & 0.0115 & 0.0268 & 0.43 & $\begin{array}{r}<5.14 \\
<10.92\end{array}$ & \\
\hline 17.500 & 10.088 & 10.142 & 10.188 & 0.100 & 0.0076 & 0.0301 & 0.25 & & \\
\hline 18.000 & 9.439 & 9.547 & 9.524 & 0.108 & 0.0097 & 0.0136 & 0.71 & & \\
\hline 18.500 & 9.046 & 9.151 & 9.103 & 0.105 & 0.0083 & 0.0086 & 0.97 & & \\
\hline 19.000 & 8.791 & 8.907 & 8.829 & 0.116 & 0.0104 & 0.0066 & 1.58 & & \\
\hline 19.500 & 8.640 & 8.751 & 8.671 & 0.111 & 0.0098 & 0.0055 & 1.78 & & \\
\hline 20.000 & 8.568 & 8.676 & 8.611 & 0.108 & 0.0089 & 0.0040 & 2.23 & & \\
\hline 20.500 & 8.572 & 8.673 & 8.615 & 0.101 & 0.0078 & 0.0038 & 2.05 & & \\
\hline 21.000 & 8.665 & 8.775 & 8.705 & 0.110 & 0.0093 & 0.0045 & 2.07 & & \\
\hline 21.500 & 8.850 & 8.952 & 8.864 & 0.102 & 0.0092 & 0.0046 & 2.00 & & \\
\hline 22.000 & 9.136 & 9.182 & 9.097 & 0.085 & 0.0055 & 0.0098 & 0.56 & & \\
\hline 22.500 & 9.515 & 9.405 & 9.363 & 0.152 & 0.0186 & 0.0096 & 1.94 & & \\
\hline 23.000 & 10.001 & 9.778 & 9.767 & 0.234 & 0.0554 & 0.0124 & 4.47 & & \\
\hline 23.500 & 10.421 & 10.204 & 10.239 & 0.217 & 0.0407 & 0.0196 & 2.08 & & \\
\hline 24.000 & 10.868 & 10.671 & 10.592 & 0.276 & 0.0606 & 0.0203 & 2.98 & & \\
\hline 24.500 & 11.295 & 11.151 & 11.134 & 0.161 & 0.0235 & 0.0153 & 1.54 & & \\
\hline 25.000 & 11.777 & 11.690 & 11.717 & 0.087 & 0.0060 & 0.0112 & 0.54 & & \\
\hline $\mathrm{mm}$ & $\mathrm{mm}$ & $\mathrm{mm}$ & $\mathrm{mm}$. & $\mathrm{mm}$. & & & & & \\
\hline
\end{tabular}

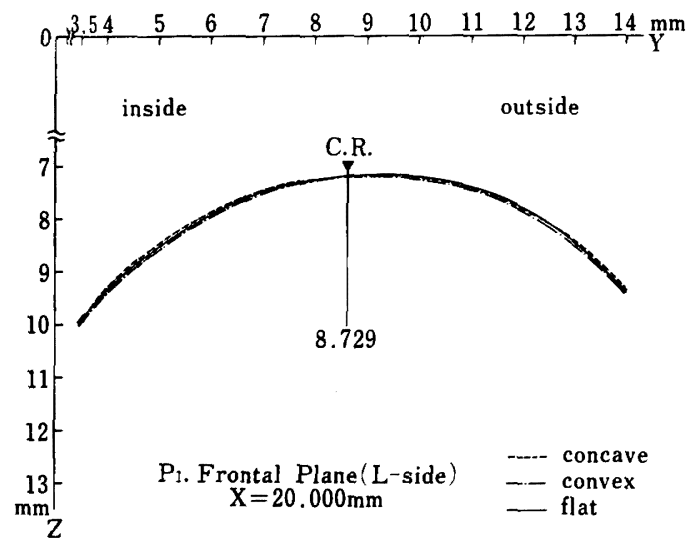

図 19 被験者 $\mathrm{P}_{2}$ における C.B.P.の形態の差による レジンフォッサの平均值（前頭面）

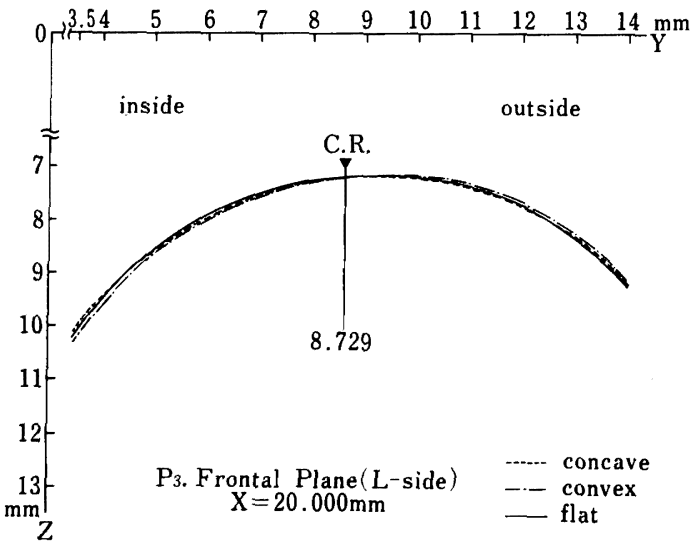

図 20 被験者 $\mathrm{P}_{3}$ における C.B.P. の形態の差による レジンフォッサの平均值（前頭面） 
表 12 被駼者 $\mathrm{Ps}$ について平面, 凸面, 凹面のプレートにおけるレジン フォッサのY 軸上での $\mathrm{Z}$ 座標の平均值と統計值

\begin{tabular}{|c|c|c|c|c|c|c|c|c|c|}
\hline \multirow{2}{*}{$\mathrm{X}$} & \multicolumn{3}{|c|}{ Z } & \multirow{2}{*}{ DT } & \multirow{2}{*}{$\mathrm{V}_{\mathrm{A}}$} & \multirow{2}{*}{$V_{E}$} & \multirow{2}{*}{ Fs } & \multirow{2}{*}{$F_{(1 \%)}^{(5 \%)}$} & \multirow{2}{*}{ 判定 } \\
\hline & $M_{A}$ & $\mathrm{M}_{\mathrm{B}}$ & $\mathrm{Mc}$ & & & & & & \\
\hline 16.500 & 9.790 & 9.979 & 10.024 & 0.234 & 0.0461 & 0.0183 & 2.52 & $<\begin{array}{r}5.14 \\
<10.92\end{array}$ & \\
\hline 17.000 & 9.044 & 9.184 & 9.113 & $0.140^{\circ}$ & 0.0146 & 0.0056 & 2.61 & & \\
\hline 17.500 & 8.532 & 8.645 & 8.579 & 0.113 & 0.0096 & 0.0021 & 4.57 & & \\
\hline 18.000 & 8.165 & 8.255 & 8.198 & 0.090 & 0.0062 & 0.0016 & 3.87 & & \\
\hline 18.500 & 7.890 & 7.984 & 7.984 & 0.094 & 0.0042 & 0.0012 & 3.30 & & \\
\hline 19.000 & 7.699 & 7.765 & 7.719 & 0.066 & 0.0035 & 0.0010 & 3.50 & & \\
\hline 19.500 & 7.581 & 7.642 & 7.594 & 0.061 & 0.0032 & 0.0090 & 3.56 & & \\
\hline 20.000 & 7.531 & 7.590 & 7.539 & 0.059 & 0.0031 & 0.0009 & 3.44 & & \\
\hline 20.500 & 7.523 & 7.586 & 7.537 & 0.063 & 0.0033 & 0.0011 & 3.00 & & \\
\hline 21.000 & 7.580 & 7.636 & 7.585 & 0.056 & 0.0029 & 0.0014 & 2.07 & & \\
\hline 21.500 & 7.699 & 7.747 & 7.701 & 0.048 & 0.0022 & 0.0019 & 1.58 & & \\
\hline 22.000 & 7.896 & 7.884 & 7.854 & 0.042 & 0.0015 & 0.0015 & 1.00 & & \\
\hline 22.500 & 8.161 & 8.049 & 8.046 & 0.115 & 0.0130 & 0.0038 & 3.42 & & \\
\hline 23.000 & 8.468 & 8.315 & 8.339 & 0.153 & 0.0203 & 0.0057 & 3.56 & & \\
\hline 23.500 & 8.816 & 8.632 & 8.705 & 0.184 & 0.0258 & 0.0058 & 3.12 & & \\
\hline 24.000 & 9.190 & 9.024 & 9.005 & 0.185 & 0.0312 & 0.0097 & 3.22 & & \\
\hline 24.500 & 9.580 & 9.448 & 9.456 & 0.132 & 0.0164 & 0.0092 & 1.78 & & \\
\hline 25.000 & 10.008 & 9.895 & 9.976 & 0.113 & 0.0102 & 0.0045 & 2.27 & & \\
\hline 25.500 & 10.466 & 10.417 & 10.511 & 0.094 & 0.0067 & 0.0036 & 1.86 & & \\
\hline 26.000 & 10.912 & 10.986 & 11.047 & 0.135 & 0.0136 & 0.0088 & 1.54 & & \\
\hline 26.500 & 11.385 & 11.559 & 11.513 & 0.174 & 0.0245 & 0.0174 & 1.41 & & \\
\hline $\begin{array}{r}27.000 \\
\mathrm{~mm} .\end{array}$ & $\begin{array}{r}11.765 \\
\mathrm{~mm} .\end{array}$ & $\begin{array}{r}12.016 \\
\mathrm{~mm} .\end{array}$ & $\begin{array}{r}11.911 \\
\mathrm{~mm} .\end{array}$ & $\begin{array}{r}0.251 \\
\mathrm{~mm} .\end{array}$ & 0.0476 & 0.0185 & $2: 57$ & & \\
\hline
\end{tabular}

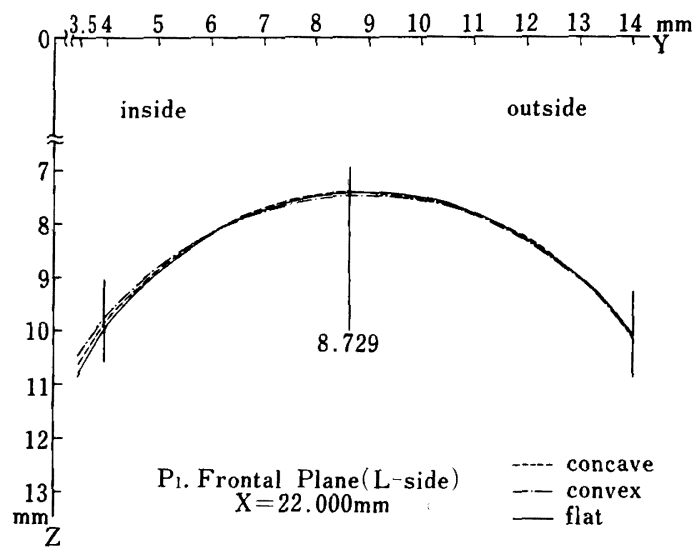

図 21 被験者 $\mathrm{P}_{1}$ における C.B.P.の形態の差による レジンフォッサの平均值（前頭面）

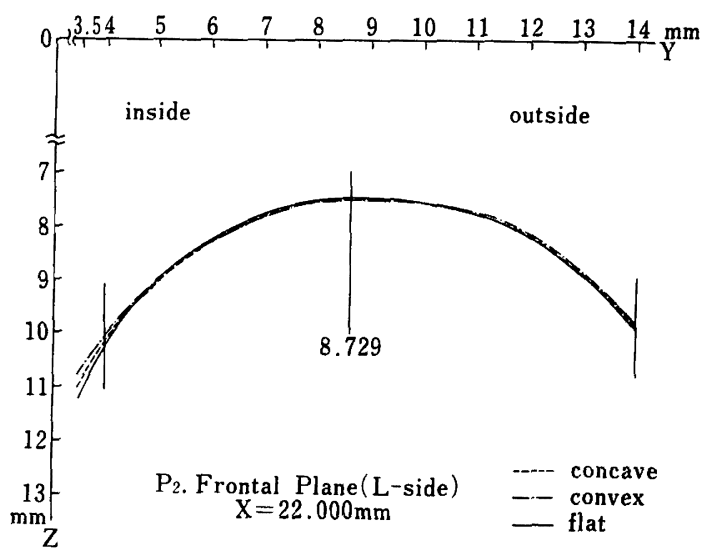

図 22 被験者 $\mathrm{P}_{2}$ における C.B.P. の形態の差による レジンフォッサの平均値（前頭面） 
表 13 被験者 $\mathrm{P}_{3}$ について平面, 凸面, 凹面のプレートにおけるレジン フォッサのY 軸上での Z 座標の平均値と統計値

\begin{tabular}{|c|c|c|c|c|c|c|c|c|c|}
\hline \multirow{2}{*}{$\mathrm{X}$} & \multicolumn{3}{|c|}{$\mathrm{Z}$} & \multirow{2}{*}{$\mathrm{DT}_{\mathrm{T}}$} & \multirow{2}{*}{$\mathrm{VA}_{\mathrm{A}}$} & \multirow{2}{*}{ VE } & \multirow{2}{*}{$\mathrm{Fs}$} & \multirow{2}{*}{$F_{(1 \%)}^{(5 \%)}$} & \multirow{2}{*}{ 判定 } \\
\hline & $\mathrm{M}_{\mathrm{A}}$ & $M_{B}$ & $\mathrm{Mc}$ & & & & & & \\
\hline 16.000 & 10.359 & 10.581 & 10.496 & 0.222 & 0.0374 & 0.0309 & 1.21 & $<5.14$ & \\
\hline 16.500 & 9.227 & 9.334 & 9.373 & 0.146 & 0.0173 & 0.0070 & 2.47 & & \\
\hline 17.000 & 8.581 & 8.651 & 8.646 & 0.070 & 0.0046 & 0.0021 & 2.19 & & \\
\hline 17.500 & 8.133 & 8.176 & 8.175 & 0.043 & 0.0017 & 0.0011 & 1.55 & & \\
\hline 18.000 & 7.794 & 7.827 & 7.816 & 0.033 & 0.0009 & 0.0008 & 1.12 & & \\
\hline 18.500 & 7.529 & 7.566 & 7.555 & 0.037 & 0.0011 & 0.0006 & 1.83 & & \\
\hline 19.000 & 7.350 & 7.384 & 7.374 & 0.034 & 0.0009 & 0.0006 & 1.50 & & \\
\hline 19.500 & 7.241 & 7.265 & 7.264 & 0.024 & 0.0006 & 0.0004 & 1.50 & & \\
\hline 20.000 & 7.201 & 7.207 & 7.207 & 0.006 & 0.0002 & 0.0003 & 0.67 & & \\
\hline 20.500 & 7.217 & 7.216 & 7.217 & 0.001 & 0.0001 & 0.0004 & 0.25 & & \\
\hline 21.000 & 7.278 & 7.277 & 7.265 & 0.013 & 0.0002 & 0.0005 & 0.40 & & \\
\hline 21.500 & 7.378 & 7.366 & 7.350 & 0.088 & 0.0006 & 0.0004 & 1.50 & & \\
\hline 22.000 & 7.564 & 7.528 & 7.509 & 0.055 & 0.0024 & 0.0009 & 2.67 & & \\
\hline 22.500 & 7.800 & 7.735 & 7.705 & 0.095 & 0.0071 & 0.0023 & 3.09 & & \\
\hline 23.000 & 8.077 & 8.014 & 7.942 & 0.135 & 0.0136 & 0.0055 & 2.47 & & \\
\hline 23.500 & 8.376 & 8.304 & 8.268 & 0.108 & 0.0091 & 0.0051 & 1.78 & & \\
\hline 24.000 & 8.727 & 8.652 & 8.669 & 0.075 & 0.0047 & 0.0069 & 0.68 & & \\
\hline 24.500 & 9.107 & 9.021 & 9.109 & 0.088 & 0.0076 & 0.0070 & 1.09 & & \\
\hline 25.000 & 9.509 & 9.434 & 9.603 & 0.169 & 0.0216 & 0.0078 & 2.77 & & \\
\hline 25.500 & 9.953 & 9.897 & 10.136 & 0.183 & 0.0468 & 0.0153 & 3.06 & & \\
\hline 26.000 & 10.406 & 10.433 & 10.646 & 0.240 & 0.0519 & 0.0312 & 1.66 & & \\
\hline 26.500 & 10.859 & 11.022 & 11.127 & 0.268 & 0.0547 & 0.0336 & 1.63 & & \\
\hline 27.000 & 11.286 & 11.514 & 11.521 & 0.235 & 0.0535 & 0.0298 & 1.80 & & \\
\hline 27.500 & 11.636 & 11.888 & 11.848 & 0.252 & 0.0548 & 0.0250 & 2.19 & & \\
\hline 28.000 & 11.940 & 12.164 & 12.087 & 0.224 & 0.0388 & 0.0274 & 1.42 & & \\
\hline $\mathrm{mm}$. & $\mathrm{mm}$ & $\mathrm{mm}$ & $\mathrm{mm}$ & $\mathrm{mm}$. & & & & & \\
\hline
\end{tabular}

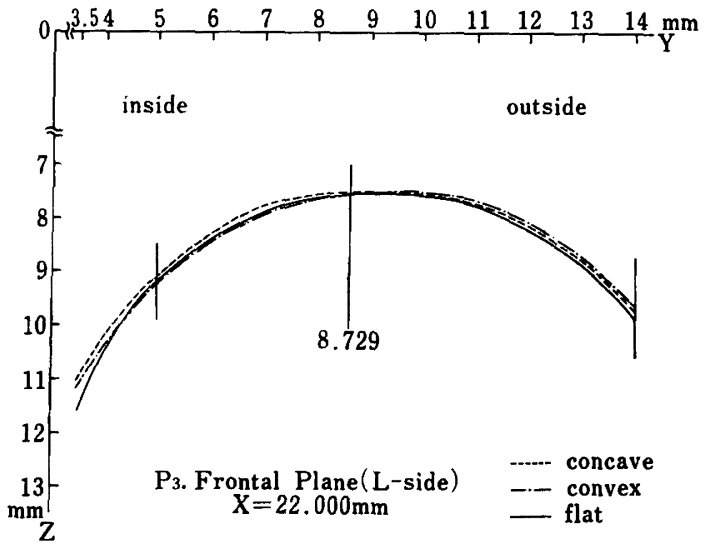

図 23 被験者 $\mathrm{P}_{3}$ における C.B.P.の形態の差による レジンフォッサの平均值（前頭面）

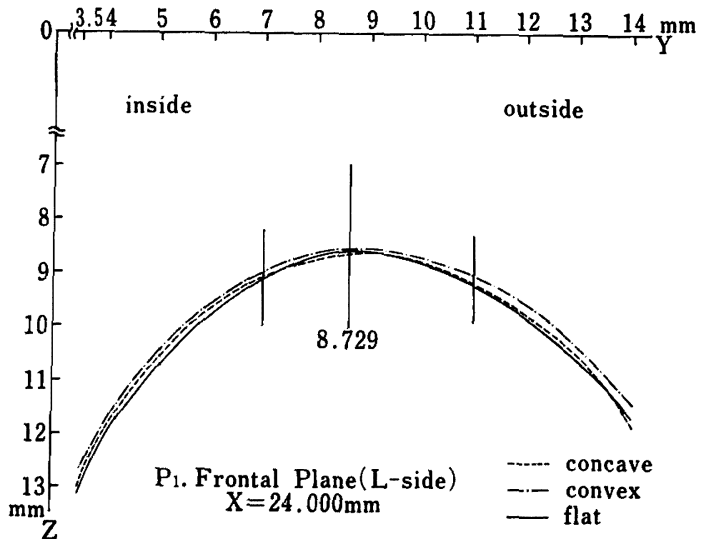

図 24 被験者 $\mathrm{P}_{1}$ における C.B.P. の形態の差による レジンフォッサの平均値（前頭面） 
表 14 被験者 $\mathrm{P}_{3}$ について平面，凹面，凹面のプレートにおけるレジン フォッサのY軸上での Z 座標の平均値と統計值

\begin{tabular}{|c|c|c|c|c|c|c|c|c|c|}
\hline \multirow{2}{*}{$\mathrm{X}$} & \multicolumn{3}{|c|}{$\mathrm{Z}$} & \multirow{2}{*}{ DT } & \multirow{2}{*}{$\mathrm{V}_{\mathrm{A}}$} & \multirow{2}{*}{$V_{E}$} & \multirow{2}{*}{ Fs } & \multirow{2}{*}{$F_{(1 \%)}^{(5 \%)}$} & \multirow{2}{*}{ 判定 } \\
\hline & $\mathrm{M}_{\mathrm{A}}$ & $\mathrm{MB}$ & $\mathrm{Mc}_{\mathrm{C}}$ & & & & & & \\
\hline 16.500 & 9.573 & 9.616 & 9.582 & 0.043 & 0.0016 & 0.0091 & 0.18 & $\begin{array}{r}<5.14 \\
<10.92\end{array}$ & \\
\hline 17.000 & 8.845 & 8.855 & 8.879 & 0.034 & 0.0010 & 0.0052 & 0.19 & & \\
\hline 17.500 & 8.351 & 8.357 & 8.382 & 0.031 & 0.0008 & 0.0033 & 0.24 & & \\
\hline 18.000 & 7.998 & 7.994 & 8.008 & 0.014 & 0.0002 & 0.0019 & 0.11 & & \\
\hline 18.500 & 7.741 & 7.726 & 7.752 & 0.026 & 0.0005 & 0.0016 & 0.31 & & \\
\hline 19.000 & 7.560 & 7.535 & 7.563 & 0.028 & 0.0007 & 0.0012 & 0.58 & & \\
\hline 19.500 & 7.438 & 7.409 & 7.459 & 0.050 & 0.0019 & 0.0009 & 2.11 & & \\
\hline 20.000 & 7.383 & 7.350 & 7.405 & 0.055 & 0.0024 & 0.0005 & 4.80 & & \\
\hline 20.500 & 7.389 & 7.346 & 7.407 & 0.061 & 0.0030 & 0.0006 & 5.00 & & \\
\hline 21.000 & 7.461 & 7.402 & 7.433 & 0.059 & 0.0026 & 0.0012 & 2.17 & & \\
\hline 21.500 & 7.605 & 7.508 & 7.560 & 0.097 & 0.0071 & 0.0018 & 3.94 & & \\
\hline 22.000 & 7.769 & 7.691 & 7.709 & 0.078 & 0.0051 & 0.0022 & 2.32 & & \\
\hline 22.500 & 8.025 & 7.989 & 7.928 & 0.097 & 0.0072 & 0.0054 & 1.33 & & \\
\hline 23.000 & 8.325 & 8.281 & 8.184 & 0.141 . & 0.0157 & 0.0057 & 2.75 & & \\
\hline 23.500 & 8.642 & 8.623 & 8.508 & 0.134 & 0.0157 & 0.0066 & 2.38 & & \\
\hline 24.000 & 9.003 & 9.021 & 8.909 & 0.112 & 0.0109 & 0.0148 & 0.74 & & \\
\hline 24.500 & 9.396 & 9.452 & 9.354 & 0.098 & 0.0072 & 0.0279 & 0.26 & & \\
\hline 25.000 & 9.810 & 9.906 & 9.846 & 0.096 & 0.0071 & 0.0379 & 0.19 & & \\
\hline 25.500 & 10.258 & 10.421 & 10.345 & 0.163 & 0.0201 & 0.0500 & 0.40 & & \\
\hline 26.000 & 10.711 & 10.978 & 10.849 & 0.267 & 0.0537 & 0.0656 & 0.82 & & \\
\hline 26.500 & 11.149 & 11.475 & 11.327 & 0.326 & 0.0801 & 0.0669 & 1.20 & & \\
\hline $\begin{array}{r}27.000 \\
\mathrm{~mm} .\end{array}$ & $\begin{array}{r}11.533 \\
\mathrm{~mm} .\end{array}$ & $\begin{array}{c}11.883 \\
\mathrm{~mm} .\end{array}$ & $\begin{array}{r}11.722 \\
\mathrm{~mm} .\end{array}$ & $\begin{array}{r}0.350 \\
\mathrm{~mm} .\end{array}$ & 0.0923 & 0.0496 & 1.86 & & \\
\hline
\end{tabular}

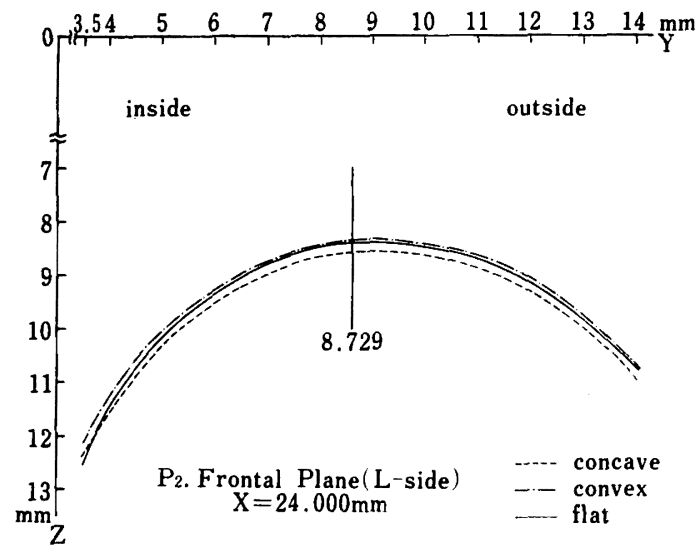

図 25 被験者 $\mathrm{P}_{2}$ における C.B.P. の形態の差による レジンフォッサの平均値（前頭面）

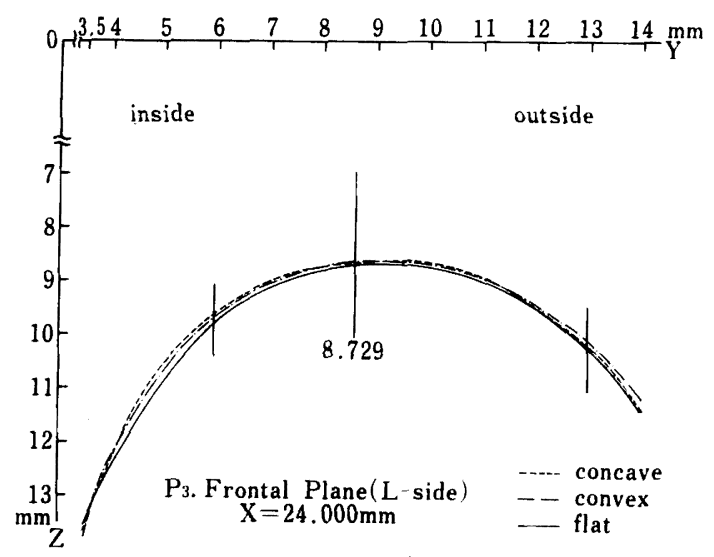

図 26 被験者 $\mathrm{P}_{3}$ における C.B.P.の形態の差による レジンフォッサの平均值（前頭面） 
表 15 被唋者 $\mathrm{P}_{3}$ について平面, 凸面, 凹面のプレートにおけるレジン フォッサのY軸上でのZ座標の平均値と統計值

\begin{tabular}{|c|c|c|c|c|c|c|c|c|c|}
\hline & & & & & & & \multicolumn{3}{|c|}{$(Y=13.000 \mathrm{~mm})$} \\
\hline \multirow{2}{*}{$X$} & \multicolumn{3}{|c|}{2} & \multirow{2}{*}{ DT } & \multirow{2}{*}{$V_{A}$} & \multirow{2}{*}{$\mathrm{VE}$} & \multirow{2}{*}{ Fs } & \multirow{2}{*}{$F_{(1 \%)}^{(5 \%)}$} & \multirow{2}{*}{ 判定 } \\
\hline & $M_{A}$ & $\mathrm{MB}_{\mathrm{B}}$ & Mc & & & & & & \\
\hline 17.500 & 9.786 & 9.685 & 9.743 & 0.101 & 0.0076 & 0.0143 & 0.53 & $<\begin{array}{r}5.14 \\
<10.92\end{array}$ & \\
\hline 18.000 & 9.210 & 9.121 & 9.181 & 0.089 & 0.0062 & 0.0044 & 1.41 & & \\
\hline 18.500 & 8.835 & 8.751 & 8.798 & 0.084 & 0.0054 & 0.0034 & 1.59 & & \\
\hline 19.000 & 8.575 & 8.495 & 8.540 & 0.080 & 0.0049 & 0.0022 & 2.23 & & \\
\hline 19.500 & 8.433 & 8.348 & 8.411 & 0.085 & 0.0058 & 0.0020 & 2.90 & & \\
\hline 20.000 & 8.379 & 8.291 & 8.339 & 0.088 & 0.0058 & 0.0021 & 2.76 & & \\
\hline 20.500 & 8.387 & 8.282 & 8.336 & 0.105 & 0.0082 & 0.0020 & 4.10 & & \\
\hline 21.000 & 8.445 & 8.347 & 8.407 & 0.098 & 0.0074 & 0.0033 & 2.24 & & \\
\hline 21.500 & 8.623 & 8.493 & 8.546 & 0.130 & 0.0127 & 0.0055 & 2.31 & & \\
\hline 22.000 & 8.898 & 8.731 & 8.766 & 0.167 & 0.0233 & 0.0071 & 3.28 & & \\
\hline 22.500 & 9.189 & 9.018 & 9.054 & 0.171 & 0.0243 & 0.0106 & 2.29 & & \\
\hline 23.000 & 9.511 & 9.348 & 9.382 & 0.163 & 0.0220 & 0.0165 & 1.33 & & \\
\hline 23.500 & 9.873 & 9.701 & 9.770 & 0.172 & 0.0225 & 0.0248 & 0.91 & & \\
\hline 24.000 & 10.260 & 10.074 & 10.215 & 0.186 & 0.0284 & 0.0319 & 0.89 & & \\
\hline 24.500 & 10.690 & 10.484 & 10.693 & 0.209 & 0.0430 & 0.0362 & 1.19 & & \\
\hline $\begin{array}{r}25.000 \\
\mathrm{~mm} .\end{array}$ & $\begin{array}{r}11.132 \\
\mathrm{~mm} .\end{array}$ & $\begin{array}{r}10.949 \\
\mathrm{~mm} .\end{array}$ & $\begin{array}{r}11.176 \\
\mathrm{~mm} .\end{array}$ & $\begin{array}{r}0.227 \\
\mathrm{~mm} .\end{array}$ & 0.0433 & 0.0601 & 0.72 & & \\
\hline
\end{tabular}

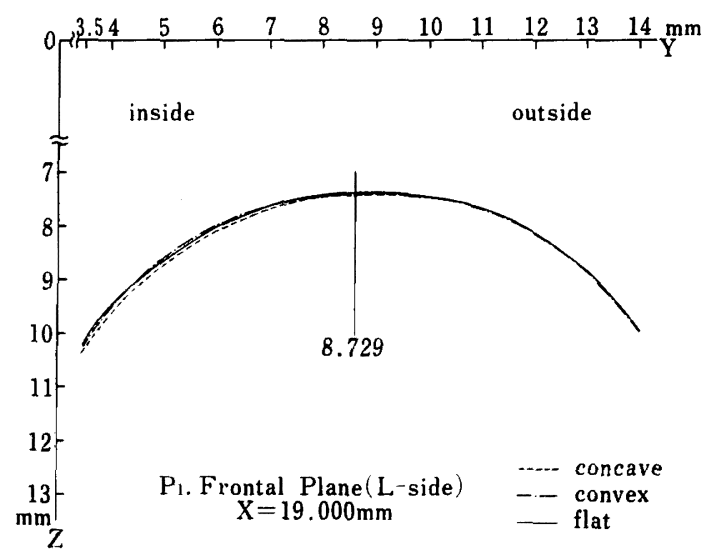

図 27 被験者 $P_{1}$ における C.B.P. の形態の差による レジンフォッサの平均值（前頭面）

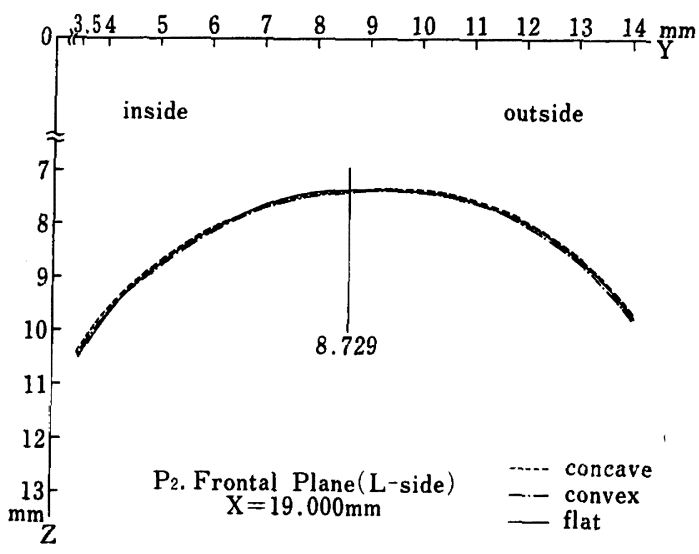

図 28 被験者 $\mathrm{P}_{2}$ におけけ C.B.P.の形態の差による レジンフォッサの平均值（前頭面） 


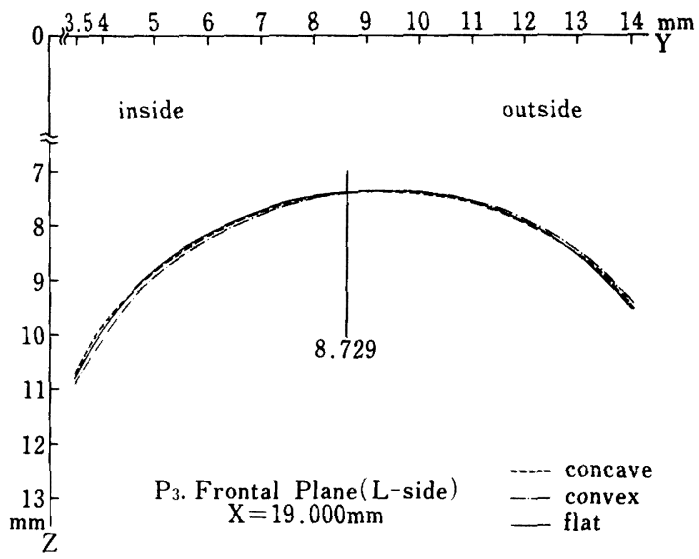

図 29 被験者 $\mathrm{P}_{3}$ における C.B.P. の形悲の差による レジンフォッサの平均值（前頭面）

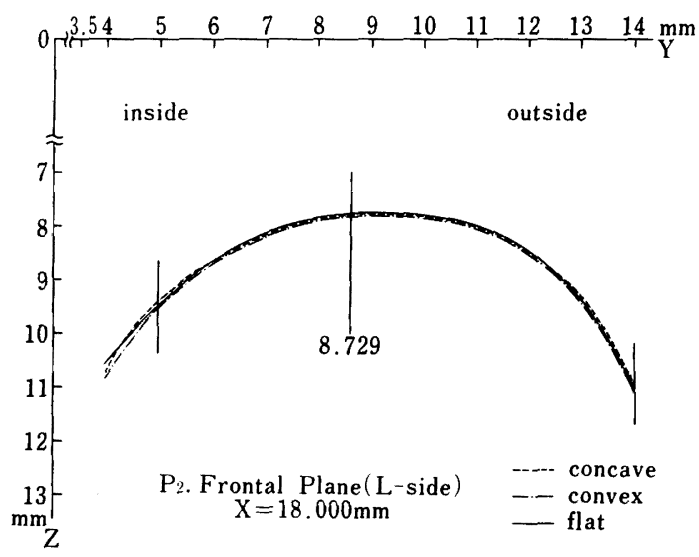

図 31 被験者 $\mathrm{P}_{2}$ における C.B.P.の形態の差による レジンフォッサの平均值（前頭面）

おいてもそのばらつきは $200 \mu$ 以下であった（図 27〜 29).

(5) $\mathrm{X}=18.000 \mathrm{~mm}$ (中心位より後方) の線上

前頭面上で中心位を通る位置 $(X=20.000 \mathrm{~mm})$ より 後方の $\mathrm{X}=18.000 \mathrm{~mm}$ の線上で $200 \mu$ 以下のばらつき を示したのは，中心位より内側では， $P_{1}$ で約 $2.5 \mathrm{~mm}$, $\mathrm{P}_{2}, \mathrm{P}_{3}$ で約 $3.5 \mathrm{~mm}$ までであった. 中心位より外側で は, $\mathrm{P}_{1}$ で約 $5.0 \mathrm{~mm}, \mathrm{P}_{2}, \mathrm{P}_{3}$ で約 $5.5 \mathrm{~mm}$ までであった (図 30〜32).

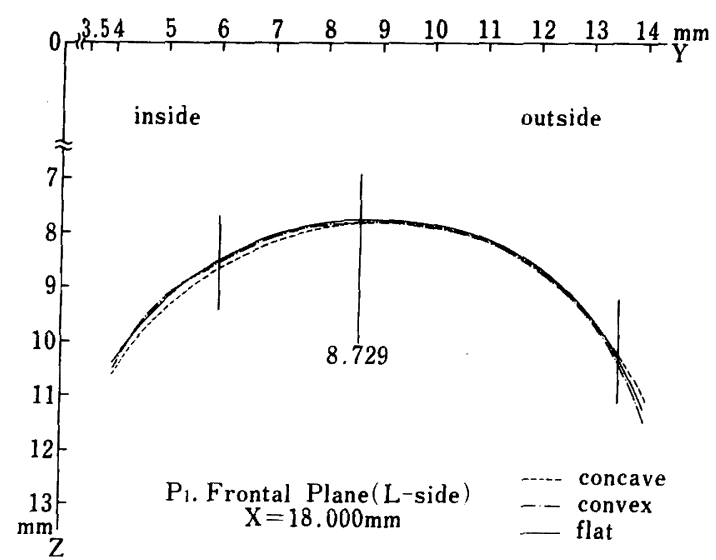

図 30 被験者 $\mathrm{P}_{1}$ における C.B.P. の形態の差による レジンフォッサの平均值（前頭面）

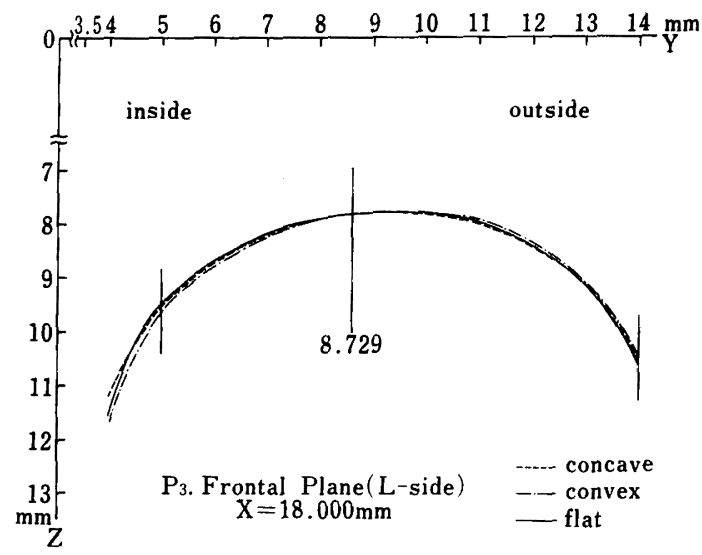

図 32 被験者 $\mathrm{P}_{3} に お$ にる C.B.P.の形態の差による レジンフォッサの平均值（前頭面）

\section{第 4 章 考 察}

1） セントラルペアリングプレート形態の顆路に対す る影響

修復物はひとの下影運動を模做した咬合器上で製作さ れるために, 種々の下喕運動理論が展開されてきた.す なわち Monson ${ }^{31)}$ の半径 4インチの球面上での䫑運動 説, Hall ${ }^{32)}$ の円錐形頢運動説, Gysi ${ }^{33)}$ の軸学説, Bennett 運動説 ${ }^{34)}$, 矢崎の咬頭展開説, $\mathrm{McCollum}^{35)}$ のナソ ロジーなどがそれである.しかし、これらの大部分は下 䪽運動が複雑な運動であることを理解しつつも, 咬合器 の顆路角調節部は平面として理論展開を行っているもの 
が多レ.

下頺運動を直接目でたしかめる方法としては $\mathrm{Gysi}^{33)}$ が C.B.P. を用い, ゴシックアーチ描記法を確立した が，その後に開発された複雑な調節機構を持つ咬合器で も下頻運動描記法は依然として単純な形態を持った平面 の C.B.P. を使用するものが多い. C.B.P.の形態が異な ることにより誘導描記される下影頭の運動軌跡は影響を 受けるだろうという疑問があった.

Clayton ${ }^{17)}$ は平面，凸面および凹面の C.B.P.を用い， パントグラフ法により観察し， V.D. が変化しない場合 は下䫑運動軌跡に影響を与えないという結果を得てい る.

鶴見 ${ }^{18)}$ は歯の咬合面そのままを誘導面とした場合と， 平面の C.B.P. を用いV.D. を挙上した, いわゆる咬合 面非誘導とした場合とについて，パントグラフ法による 下額運動軌跡の運動量と運動角とについて比較し, 咬合 面非誘導型が運動範囲が広く，臨床上大切な作業側の運 動範囲が平衡側より広くなったと報告している.そし て,これは咬合挙上により関節窩に接触する下顎頭の位 圆変化と C.B.P.の平板上の滑走のため運動再現性が低 下したためであろうと述べている。

著者は TMJ 咬合器を用いて平面，および2インチの 半径をもつ凸面と凹面のそれぞれ形態の異なる C.B.P. を用い，同一の V.D. でチューインさせ形成したレジン フォッサの形態を, 三次元測定器を用い計測したとこ ろ，いずれも影響がないことが解った，しかし，著者は V.D.は C.O. より平均約 $10 \mathrm{~mm}$ 挙上された同一被験者 の一定の䝷位におけるレジンフォッサの形態の比較であ り，V.D. を直接に変化させた影響について明らかにし ていないので, 今後, V.D. を変化させた点について追 試する必要があろう。

\section{2）チューイン時の C.B.P. の形態について}

本実験の目的であるアンテリオールガイダンスを変化 させた時のポステリオールガイダンスへの影響を調べる ため, 半径 2 インチの彎曲を付与した C.B.P. を使用し た. その理由は TMJ 咬合器付属のクラッチフォーミン グバイトフォークは半径 4 インチの曲面であり, これで は曲が弱く, 本実験の目的であるアンテリオールガイ ダンスを変化させ，凹面と四面とするためにはより強い 禁曲のむのを使用しなければならない.しかし，基礎実 験の結果 2 インチ以下の縍曲の強いものは被験者がい すれもチューインしにくいと訴えたので，2インチの C.B.P. を使用することにした. また平面の C.B.P.を採
用したのは一般的なゴシックアーチトレーシングの際は 平面の C.B.P. を用いるものが多いからである.

本研究の結果から，C.B.P. が平面，凸面あるいは仙 面でも機能域相当部のレジンフォッサの形態に有意差が なかったことより，一定の V.D. であれば，アンテリオ ールガイダンスのポステリオールガイダンスへの影響は ないものと思われるが V.D. の相違による影響について は不明である，C.B.P，の形態を変えてみた結果，凹面 の C.B.P. が最もチューインしやすく, 被験者はいずれ も，下顎運動が楽で疲労も少なく，顎関節部の異和感も ないと述べた. また平面の C.B.P. は被験者自身の下顎 側方運動のみが不安定となる以外は，凹面の C.B.P. と 同様であるという意見を得た，それに比較して，凹面の プレートはチューインしにくく，下顊運動も困難で，䪽 関節部の疲労感・痛みを訴えるものもあった.このこと より，パントグラフあるいはチューイン法を用い，運動 軌跡を採得するためには，凹面の C.B.P. を用いること が最良であろうと思われる.

\section{3）再現性に関する問題点}

(a) 機能域を $2 \mathrm{~mm}$ とした理由

咬合器の再現性について言及するために，生体の機能 域範囲をどのくらいに定めたらよいかが問題である.こ の点に関し, Hildebrand ${ }^{36)}$, Reumuth ${ }^{36)}, K_{\text {urth }}{ }^{37)}$,

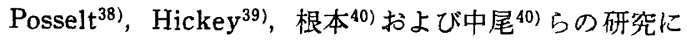
よれば，正常咬合者の咬合接触滑走範囲は咬頭嵌 合位 (中心咬合位) から約 1〜2 $\mathrm{mm}$ であると述べている，そ こで，本論文において臨床上再現されるべき機能域は咬 合面でなく下顎頭部で $2 \mathrm{~mm}$ の運動範囲とした. この範 囲における C.B.P. 間のばらつきについて検討したとこ ろ平均 $50 \mu$ であり, 中心位では平均 $4 \mu$ 程度であった.

以上のことから TMJ 咬合器では C.B.P. の形態を変 化させても機能域に関しては影響を受けず，中心位での 再現性は非常に良好であると考えられる.

(b) ばらつきの許容範囲

$200 \mu$ 以下のばらつきをもって TMJ 咬合器が C.B.P. の形態による影響を受けないと判断した根拠は, 長谷

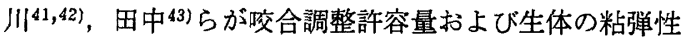
に対する咬合器の補正とを考え合わせ歯冠補緅物の口腔 内での咬合調整量が $200 \mu$ 程度になる範囲内での下顎運 動が咬合器で再現できることがのぞましいことおよび長 谷川44)らの咬合器の再現性に関して, グラフィックトレ ーシングとチェックバイト法とによる咬合器運動経路の 理論的差は平均 $230 \mu$ であるということなどより，下顎 
$64-258$

頭部で $200 \mu$ 以下のばらつきであれば臨床上問題がない そ判断した．本実験において矢状面上で中心位より約 4.0 6.0 mm 前方位で $200 \mu$ 以下のばらつきであった. 機能域内の $2 \mathrm{~mm}$ では平均 $50 \mu$ 以内, 中心位では平均 $4 \mu$ のばらつきであった. 以上のことから TMJ 咬合器 は，一定の増加された V.D. という条件下においてであ るが，C.B.P.の影響を受けず，その再現性は良好であ った.

\section{4）レジンフォッサの部位によるばらつき}

一般的にパントグラフにより下額運動軌跡を描記させ た場合を想定し，顆頭球の動きをレジンフォッサにおけ る位置と対比させてみた.この際図 2 に示すように中心 位を原点とし, 矢状面上の $\mathrm{Y}=8.729 \mathrm{~mm}$ の線を $\mathrm{Y}$ 軸, 前頭面上の $\mathrm{X}=20.000 \mathrm{~mm}$ の線をX軸とし, $\mathrm{I} \sim \mathrm{IV}$ 象 現として表わすと, 前方運動時は両顆頭球は前下方に滑 走回転するのでほほY軸上を前方に動き, 右側方運動時 は左側顆頭球は前下内方に大きく移動するので, 主に第 II象現を動き (平衡側に相当), 左側方運動時は左側顆 頭球は主として外後方にごく小さな距離で回転滑走する ので，主に第 $\mathrm{V}$ 象現を動く(作業側に相当). そこで矢 状面 $\mathrm{Y}=8.729 \mathrm{~mm}$ の図 $3 \sim 5$, 前頭面 $\mathrm{X}=20.000 \mathrm{~mm}$ の図 18 20, および前頭面上で $\mathrm{X}=22.000 \mathrm{~mm}$ と $\mathrm{X}=$ $24.000 \mathrm{~mm}$ (図 21 26) の線上での内側のばらつき (平 衡側に相当) と $X=19.000 \mathrm{~mm}, X=18.000 \mathrm{~mm}$ (図 27 〜32）の線上での外側のばらつき（作業側に相当）を比 較すれば, 明らかなように 3 人の被験者ともに中心位よ り前方のばらつきが後方のむのより大きく，また中心位 より内側 (平衡側に相当) が外側（作業側に相当）より ばらつきが大きかった.このことは TMJ 咬合器は中心 位付近の再現性がよく, また中心位より後方と外側の形 態が C.B.P. の影響を受けず，機能上大切な作業側咬頭 の傾斜角度への影響が少なく, 再現性が良好であるとい える.

\section{5）顆頭間距離を最内方の $82 \mathrm{~mm}$ に設定した理由}

一般に TMJ 咬合器を使用する際には, 咬合器の顆頭 間距離は被験者のヒンジアキシスポイント間の皮膚面間 距離にヒンジポイントインディケーターピンを一致さ せ, ヒンジボーにてフェースボートランスファーする. 咬合器上の顆頭間距離は実際の皮虚面間距離より左右側 でそれぞれ $9.5 \mathrm{~mm}$ 内側に入った位置に固定される. パ ントグラフ法においては前方描記板上のゴシックアーチ により被験者固有の顆頭間距離に再調整するが, TMJ
咬合器においてはその位置のままレジンフォッサを形成 してしまう，被験者固有の顆頭間軸より外方では下顥運 動は拡大され, 内方では縮小される. 田中年 47)がテレ ダイン咬合器設計の際, 顆頭間距離を本来の距離より狭 くすることにより，咬合器顆頭の運動方向を一定方向に 集約できるという理論を発表しているが，本実験でも咬 合器顆頭間距離を最内方の $82 \mathrm{~mm}$ に固定し, レジンフ オッサを形成すれば，より単純化された形態になるだろ うと考えた.

被験者 3 名にそれぞれの C.B.P. を用いチューインさ せ, レジンフォッサを形成しても約 $6 \mathrm{~mm}$ 以内の形態は 非常に一致し, 約 $10 \mathrm{~mm}$ 前方においても約 $500 \mu \sim 700 \mu$ のばらっきであることより, 被験者を増せば平均値的形 態を持った半調節性咬合器の設計が可能であろう。

\section{6) チューイン法とその他の咬合器調節法との比較検} 討

チューイン法の欠点 ${ }^{48)}$ として, 記録採得時抵抗がある ことにより，下䭭運動が偏ったり誘導されたりして記録 が不正確になりやすく，また口内法で行うので連動路の 確認ができず, 咬合器設定まで記録の正確さが確認でき ないことであるといわれる、また，チェックバイト法は 出発点からある運動点までを直線的に結んだ滪位の再現 は可能でも，機能時に大切な 1 2 $\mathrm{mm}$ の運動範囲では 咬合器の顆路角規制は不可能であり, 約 5 6 $\mathrm{mm}$ の運 動範囲でのみ咬合器規制が可能であると述べられてい る ${ }^{49}$. しかも頡位の再現は可能でも, 咬合器上で大切な 運動経路の再現はまったくできない，それに比較してパ ントグラフ法は以上の欠点がなく, 正確であると記載さ れている50,51)が，咬合器設定時に術者間の設定誤差が 問題52 54) になっている. 著者の研究結果からすると, C.B.P.の形態を変えても中心位付近は平均 $4 \mu$, 機能域 の $2 \mathrm{~mm}$ の範囲では平均 $50 \mu$, 約 $6 \mathrm{~mm}$ の前方運動時で も $200 \mu$ 以内のばらつきであることより, TMJ 咬合器 は臨床上必要な機能域の再現が良好で，運動再現性が優 れている有用な咬合器であると考えられる.

\section{第 5 章 結論}

チューイン法を応用した TMJ 咬合器でアンテリオー ルガイダンスを変化させた時のポステリオールガイダン スへの影響をみるために, セントラルベアリングプレー 卜を平面, 凸面および凹面の 3 種類に変え, それぞれの セントラルベアリングプレートの形態が下䫑頭の運動経 
路に相当すると考えられるレジンフォッサの形態にどの ように影響するか計測し，以下の結果を得た.

(1) 各セントラルベァリングプレートの形態を変えて も、レジンフォッサの形態には影響がなかった。

(2) TMJ 咬合器のレジンフォッサの形態は中心位か ら $2 \mathrm{~mm}$ の範囲を機能域とするならば，セントラルベ アリングプレートの形態にほとんど影響を受けなかっ た.

（3）レジンフォッサの形態は各セントラルベアリング プレート間で，中心位では平均 $4 \mu$, 中心位より $2 \mathrm{~mm}$ の範囲内で平均 $50 \mu$, 臨床上必要な範囲内では $200 \mu$ 以 下であり，TMJ 咬合器の再現性は非常に良好であっ た.

(4) どの形態のセントラルベアリングプレートでもレ ジンフォッサの形態は中心位より外側（作業側に相当） のばらつきが，内側（平衡側に相当）のそれより小さか った.すなわち，TMJ 咬合器では作業側より平衡側で の再現性が劣っていた。

(5) TMJ 咬合器の顆頭間距離を最内方に固定したと ころ, 各個人のレジンフォッサはほぼ同様の形態に集約 された.このことは例数を増すことにより，平均値的な 関節窩形態を持つ半調節性咬合器の設計が可能であろう と予測させる.

(6) 本研究の結論であるセントラルベアリングプレー トの形態を変えても，関節窩形態への影響がほとんどな かったことより, TMJ 咬合器は再現性が良好な咬合器 であることが判明した。

以上の結果より, TMJ 咬合器は臨床上有用な咬合器 であると思われる.

稿を終るにあたり，ご指導を睗った日本大学補緅学教授中 沢靕先生および本研究に直接ご指導いただいた本大学補緅学 助教授五十嵐孝義先生に深く感射の意を表し，あわせて本研 究に協力していただいた被験者諸氏および本教室の諸先生に 対し感鲋の意を表します，さらに計測に際してご協かいただ いた三豊製作所マイクロコードセンターの佐藤智男, 渡辺清 海氏に厚く㧍礼申し上げます。

\section{Summary}

Although there is a fair large literature on the reproducibility of jaw movement by a semi-adjustable articulator, researches dealing with a fully adjustable articulator are yet relatively few.

In the present study, the author was concerned with the chew-in method by use of the TMJ articular with special attention on the following three points.

i) Changes in the form corresponding to the mandibular condyle or resin fossa when the form of central bearing plate was made into either one of flat, convex and concave planes.

ii) The degree of reproducibility of the TMJ articulator.

iii) Possible effect on a range of $2 \mathrm{~mm}$ from the centric relation from a standpoint of functional movement.

By way of study material, 3 male students in their twenties at Nihon University School of Dentistry, who were in possession of normal arch and periodontal structure free from any defective tooth or teeth? were selectively used.

Exchangeable central bearing plates of flat, convex and concave (the last two being 2 inches in radius) forms were constructed on the mandibular resin clutch, where chew-ins were made in the subjects by keeping vertical occlusal dimension at the centric relation uniform or constant.

By repeating the procedure for three times to produce 9 chew-ins per individual subject, a total of 27 resin fossas were prepared. Subsequently, these resin fossas were subjected to a series of three-dimensional measurements (on the left side only) for comparative analyses.

As a result of the study, the author arrived at the following conclusions :

1. Changes in the form of each central bearing plate did not influence the form of resin fossas.

2. When the form of TMJ articulator resin fossa was regarded as being functional in a range $2 \mathrm{~mm}$ away from the centric relation, there was no appreciable influence on the part of central bearing plate.

3. The form of resin fossa between respective central bearing plates was approximately $4 \mu$ at the centric relation and, within a range of $2 \mathrm{~mm}$ from it, the mean value was $50 \mu$. As the value was less than $200 \mu$ in terms of the clinical requirements, the reproducibility of the TMJ articulator could be confirmed to be quite adequate.

4. With any form of the central bearing plates, a scatter of resin fossa forms was smaller outside the centric relation (corresponding to the working side) than inside of it (corresponding to the balancing side).

In other words, with the TMJ articular its degree of reproducibility was inferior on the balancing side rather than on the working side.

5. When condylar distance of the TMJ articulator was 
-fixed at the innermost position, the resin fossas of individual subjects were collected in more or less similar forms.

This suggests a possibility that, by increasing the number of cases, it wll be possible: to construct a semiadjustable articulator that has the average condylar fossa morphology.

6. From the fact that changes in the form of central bearing plates would not affect the form of glenoid fossa, it could be established that the TMJ articulator has an excellent degree of reproducibility.

On the strength of the above findings, it is to be concluded that the TMJ articulator is one which serves clinical purposes satisfactorily.

\section{文献}

1) Sönstebo, H. R.: C. E. Luce's recordings of mandibular movements, J. Prosth. Dent., 11: 1068 $\sim 1072,1961$

2) Johan Ulrich: The human temporomandibular joint: Kinematics and actions of the masticatory muscles, J: Prosth. Dent., 9 : 399 406, 1959.

3）鵜養 弘：䫇運動の研究（第 1 報）市䫇骨運動を固有の 点又は軸を中心とする迴旋運動と見做した場合の考察， 齒科学報, $58 ： 461 \sim 465,1953$.

4）弟盖 弘：靧運動の研究（第 2 報）下靧骨㑡方運動の観 察，齿科学報，58：577〜 586， 1953.

5）吕原寿郎, 藍稔：下䫛運動について, 畨界展望, 31 ： $29 \sim 40,1968$.

6）荒野 実：矢状面内下顎限界運動の解析，歯科学報, $77: 1 \sim 24,1977$.

7) Wilson, G. H.: The anatomy and physics of the temporomandibular joint, J. Nat. dent. Ass., $7: 414$ $\sim 420,1921$.

8) Wilson, G. H.: The anatomy and physics of the temporomandibular joint, J. Nat. dent. Ass., 28: 236 $\sim 241,1921$.

9）大石忠雄：下靧運動の立場からみた顎関節構造の研究, 補綴誌, $11 ： 197 \sim 220,1967$.

10）矢崎正方：下筫運動の解剖学的研究, 特に義雪の咀喽能 率に及注す関係に就いて(其 1 ，其 2 ，其 3，其 4)，齿 科学報, $34: 103 \sim 161,590 \sim 636,707 \sim 721,791 \sim 840$, 1929.

11) Long, J. H. : Location of the terminal hinge axis by intraoral means, J. Prosth. Dent., 23: 11 24, 1970.

12) Lucia, V. O.: Centric relation-Theory and practice, J. Prosth. Dent., 10: 849 856, 1960
13）佐久間博-... : Checkbite 法に上る矢状顆路傾斜角度の 測定に関する研究（第 1 報 基碄的実験），畨科学報， $73: 1 \sim 30, \quad 1970$.

14）佐久間博一：Checkbite 法による矢状顆路傎斜角度の 測定に関守石研究（第 2 報臨床的実験），歯科学報， $73: 31 \sim 58,1970$.

15）腰原 好：チェック・バイトについて，日本㭔科評論, $384: 45 \sim 56,1974$

16) Francisco LePera: Understanding graphic records of mandibular movements, J. Prosth. Dent., 18: 417 $\sim 424,1967$.

17) Clayton, J. A., Kotowicz, W. E. \& Myers, G. E.: Graphic recordings of mandibular movements Research criteria, J. Prosth. Dent., $25: 287 \sim 298$ 1971.

18）鶴見祐三：咬合非誘導と咬合誘導における顆路の変化 に関する研究，歯科学報，75：1401～1432，1975.

19）真柳昭紘：側方滑走運動における顆頭運動に関する研 究, 補緅誌, $14: 158 \sim 182,1970$.

20）真柳昭紘：側方滑走運動路における然曲に関する研究， 補緅誌， $17: 205 \sim 213,1973$.

21) Weinberg, L. A.: Technique for temporomandibular joint radiographs, J. Prosth. Dent., 28: 284 308, 1972.

22) Weinberg, L. A.: Temporomandibular joint function and its effect on centric relation, J. Prosth. Dent., $30: 176 \sim 195,1973$

23) Weinberg, L. A. : Temporomandibular joint function and its effect on concepts of occlusion, J. Prosth Dent., 35 : 553 566, 1976

24）河野正司：下䫛の矢状面内運動に対応する顆頭運動の 研究 (第 1 報) 断曆X線規格写真による锤察，補綴誌， $12: 135 \sim 349,1968$.

25) Waysenson, B. \& Salomon, J.: Three dimensional recordings of envelopes of motion related to mandibular movements, J. Prosth. Dent., 38 : 52 20 1977.

26）加藤吉昭：ストロボ撮影法による市顎運動, 殊に補緅学 的見地からみた運動に関する研究，日大医誌，19： 1451 1487, 1960.

27）佐久間孔毅：マルチフラッシュ装圆による有齒顎の前 後および開閉運動の研究，口病誌，26:1511〜 1536, 1959.

28）河野正司：下頡の矢状面内運動に対応する顆頭運動の 研究 (第 2 報) マルチフラッシュ装圈による矢状面運動 軸の解析，補緅誌， $12: 350 \sim 380 ， 1968$.

29) Berry, H. M. \& Hofmann, F. A. : Cineradiographic observations of temporomandibular joint function, $\mathrm{J}$. 
Prosth. Dent.. 9: 21 -23. 1959.

30) Hickey, J. C., Allison. M. L., Woelfel, J. B., Boucher, C. O. \& Stacy, R. W.: Mandibular movements in three dimensions, J. Prosth. Dent., 13: 72 92, 1963.

31) Monson, G. S.: Occlusion as applied to crown and bridge-work, J. Nat. dent. Ass., 7 : 399 420, 1920.

32) Hall, R. E. : An analysis of the development of the articulator, J. Amer. dent. Ass., 17: 3 31, 1930.

33) Gysi, A.: The problem of articulation, Dent. Cosm., $52: 1 \sim 19,1910$.

34) Bennett, N. G. : A contribution to the study of the movements of the mandible. J. Prosth. Dent., $8: 41$ $\sim 54,1958$.

35) McCollum, B. B.: Fundamentals involved in prescribing restorative dental remedies, Dent. Items Int., $61: 522 \sim 535,641 \sim 648,724 \sim 736,852 \sim 863,942$ $\sim 950,1939$.

36）石原寿郎, 長谷川成男, 藍稔: 下顎運動と咬合器 一その研究の夜明汁と現在への系譜一 $176 \sim 180$, 日本 菌科評論社, 東京, 1975. (引用)

37) Kurth, L. E.: Mandibular movements in mastication, J. Amer. dent. Ass., 29 : 1769 1790, 1942.

38) Ulf Posselt: Movement areas of the mandible, J. Prosth. Dent., $7: 375 \sim 385,1957$.

39）根本一男：有蔽類の下䫑切齿点にお汁る3 次元的遇動 限界の研究，補綴誌，6：1１4，1962.

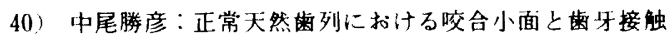
に関す万研究（後方歯牙接触位，前方滑走運動，側方滑 走運動)，補緅誌，16：289－318，1972.

41）長谷川成男, 塩沢青己：咬合器の選び方一咬合調整と近 似再現之側方運動の診断一-11)，日本粚科評論，416： 25 35, 1977.

42）長谷川成男, 塩沢育己：咬合器の選び方一咬合調整と近 似再現と側方運動の骖断一(2)，日本齿科評論，417： 25 33, 1977.

43）田中伐平：咬頭嵌合位における補緅物の高さが箱口腔 系に及洁す影暗，補緅誌，19：666～692，1976.

44）長谷川成男, 他：咬合器の再現性に関寸る検討－Graphic Tracing 法とCheckbite 法について一, 補緅誌,
$16: 138 \sim 143.1972$.

45) Tanaka, H. \& Beu, R. A.: A new semiadjustable articulator. Part I. Concept behind the new articulator, J. Prosth. Dent., 33 : 10 16, 1975.

46) Tanaka, H., Finger, I. M. \& Porter, M. M. : A new semiadjustable articulator.Part II. Adjustment of a new-concept articulator, J. Prosth. Dent. 33: 158 $\sim 168,1975$

47) Finger, I. M. \& Tanaka, H.: A new semiadjustable articulator. Part III. An investigation of the capability of the Hanau XP-51 articulator, J. Prosth. Dent., $37:$ 310 319, 1977.

48) Huffman, R. W., Regenos, J.W., \& Taylor, R.R.: Principles of Occlusion, H \& R Press., Columbus. Ohio, 1969.

49) Lauritzen, A. G.: Function, prime object of restora tive dentistry; a definite procedure to obtain it, $J$ Amer. dent. Ass., 42: 523 534, 1951.

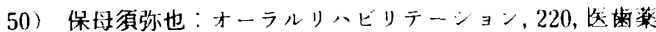
出版, 東京, 1973.

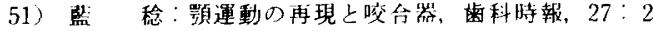
- 3, 1973

52) Watt, D. M.: A study of the reproducibility of articulator settings from graphic records of mandibular movement. Dent. Pract., 19:119 122, 1968.

53) Coye, R. B. : A study of the variability of setting a fully adjustable gnathologic articulator to a pant ographic tracing, J. Prosth. Dent, 37 : 460 $465,1977$.

54) Winstanley, R. B.: Observations on the use of the Dena pantograph and articulator, J. Prosth. Dent. 8: $660 \sim 672,1977$

55) TMJ instruments procedure manual. TMJ in strument Co., Inc., Thousand Oaks, California, 1976.

56) 大坪卓史, 他：チニーイン法による関節隼形態の变化に ついてて第 1 報)，補緅誌，21：25３0，1977.

57）林 清佐, 他：千: ーイン法による関節售形態の変化に ついて（第 2 報)，補緅誌， $22 ： 768 \sim 778 ， 1978$. 